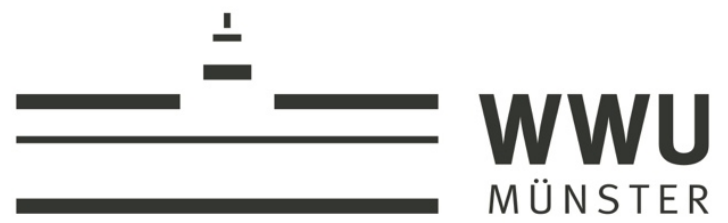

\title{
TEN-T Corridors - Stairway to Heaven or Highway to Hell?
}

by

Kathrin Goldmann and Jan Wessel

Institute of Transport Economics Münster

Working Paper

No. 31

June 2020 
(c) Westfälische Wilhelms-Universität (WWU),

Institute of Transport Economics, 2020

\section{Address}

Institut für Verkehrswissenschaft

Am Stadtgraben 9

D 48143 Münster, Germany

\section{Telephone}

+4925183-22994

Fax

+4925183-28395

\section{E-Mail}

verkehrswissenschaft@uni-muenster.de

\section{Website}

http://www.iv-muenster.de

\section{All rights reserved.}

Any reproduction, publication and reprint in the form of a different publication, whether printed or produced electronically, in whole or in part, is permitted only with the explicit written authorisation of the Westfälische WilhelmsUniversität, Institute of Transport Economics, or the author(s).

The views expressed in this paper do not necessarily reflect those of the Institute of Transport Economics or the WWU.

The Working Paper Series seeks to disseminate economic research work by the WWU, Institute of Transport Economics staff and visitors. Papers by researchers not affiliated with the WWU Institute of Transport Economics may also be considered for publication to the extent that they have been presented at research seminars/workshops organised by the institute.

The working papers published in the Series constitute work in progress circulated to stimulate discussion and critical comments. Views expressed represent exclusively the authors' own opinions.

The Series is managed by the Director of the Institute of Transport Economics. 


\title{
TEN-T Corridors - Stairway to Heaven or Highway to Hell?
}

\author{
By Kathrin Goldmann* And Jan Wessel*
}

\begin{abstract}
The European Union coordinates and co-finances supra-national transport infrastructure investments in the Trans-European Transport Network (TEN-T), which consists of road, rail, airport, and port infrastructure. To the best of our knowledge, we are the first to quantify the direct and indirect economic growth effects of newly created TEN-T core corridor roads in Eastern European countries. Both the panel data and the spatial analyses show that regional GDP growth at the NUTS3 level is between 0.5 and 2.0 percentage points higher, if a region has direct access to a newly built road. The analyses with a spatial Durbin model (SDM) show that the new construction of a TEN-T core road also causes positive spillover effects on other regions that have direct access to the corridor network, as well as on regions that are not directly connected to the corridors. The results thus indicate that the TEN-T policy, which aims to alleviate transport bottlenecks, can increase cohesion between central and peripheral regions and consequently enhance regional welfare in Eastern Europe.
\end{abstract}

JEL: R42, O18, O4\%.

Keywords: transport infrastructure, TEN-T corridors, supranational infrastructure investment, spatial Durbin model.

\section{Introduction}

The assessment of wider economic benefits of transport infrastructure investment has received considerable attention in the economic literature. Those economic impacts caused by increased accessibility can result in market expansions that achieve gains from trade and promote inter-regional integration, as well as enhancing factor market performance (Lakshmanan, 2011). However, Romp and de Haan (2007) point out that, especially in developed countries, the effect of new infrastructure depends crucially on the extent to which new investments remove bottlenecks within existing networks. Through the TEN-T corridors, the European Union (EU) aims directly at alleviating such bottlenecks which are often present at the border between countries (European Commission, 2018a).

When evaluating investment in and the performance of transport networks, spillover effects on other countries can be expected. These spillover effects increase with the number of users from other countries. For this reason, the countrywide gains from infrastructure investment are likely to be smaller than the total effect. Accordingly, Proost et al. (2011) point out that infrastructure is likely to be undersupplied on a national level when there are spillover effects. This can

* Westfälische Wilhelms-Universität Münster, Institute of Transport Economics, Am Stadtgraben 9, 48143 Münster, Germany.

The final publication in "Transportation Research Part A: Policy and Practice" is available online at: https://doi.org/10.1016/j.tra.2020.04.010 
be considered as the key motivation for supra-national subsidies for transport infrastructure, like the TEN-T policies.

Our analysis deals with the TEN-T corridor policies, its regional growth impacts and its spatial spillover effects. In order to shed more light on these effects, we use a panel data approach, as well as a SDM. We estimate whether the new construction of a core corridor road segment can enhance regional economic growth at the NUTS3 level. As there are barely any new TEN-T core corridor roads being built in the Western European countries, where infrastructure instead is often only upgraded, we focus on Eastern European countries where there are many new constructions for the TEN-T road network. The panel data analysis shows that the overall growth effect of newly constructed corridors ranges between 0.5 and 2.0 percentage points. This growth effect is due to newly gained access to the TEN-T core corridor road network. The density of this network within a NUTS3 region, on the other hand, has no significant impact on growth rates in all specifications.

The direct growth effect that is estimated with the SDM ranges between 0.9 and 1.3 percentage points, thus confirming the results of the panel analysis. By incorporating four differently specified spatial weight matrices in the SDM, we can also calculate spillover effects on regions that have direct access to the TEN$\mathrm{T}$ core corridor road network, as well as on regions that do not have direct access. The results show that the spillover effects from access to the TEN-T core corridor road network are significant and positive, thus highlighting the importance of the TEN-T policy. Furthermore, the results suggest that these spillover effects not only accrue to regions that have direct access to the TEN-T core corridor road network, but also to regions that are not directly affected by the creation of new core corridor roads.

Similar to the panel regression, the direct and indirect growth effects of the corridor density are not significant in the SDM. This underlines the importance of bottleneck-removing and accessibility-improving infrastructure projects like the TEN-T corridors, because infrastructure endowment alone does not seem to improve welfare in Eastern European member states.

The remainder of this paper is organized as follows. In Section II we give a short overview of current developments in the TEN-T initiative. Section III provides a literature review. Section IV describes the data used for the panel data analysis outlined in Section V, as well as for the spatial analysis in Section VI. We conduct various sensitivity analyses in Section VII before discussing the results in Section VIII. Section IX concludes.

\section{Trans-European Transport Network}

In the EU, transport infrastructure is regarded as one of the major means of enhancing economic and social cohesion, as well as strengthening the internal market. In accordance with this, the TEN-T initiative is set out to enhance the supra-national coordination of transport infrastructure investment. The TEN$\mathrm{T}$ initiative is therefore designed to close gaps, remove bottlenecks, and eliminate technical barriers that hamper the interoperability of the member state sub-networks (European Commission, 2018a).

The focus of this paper is on the TEN-T network, for which the European Union provides supra-national subsidies. The network consists of nine core corridors which should be completed by 2030. An overview of these corridors and the 
related TEN-T infrastructure can be seen in Figure 1.

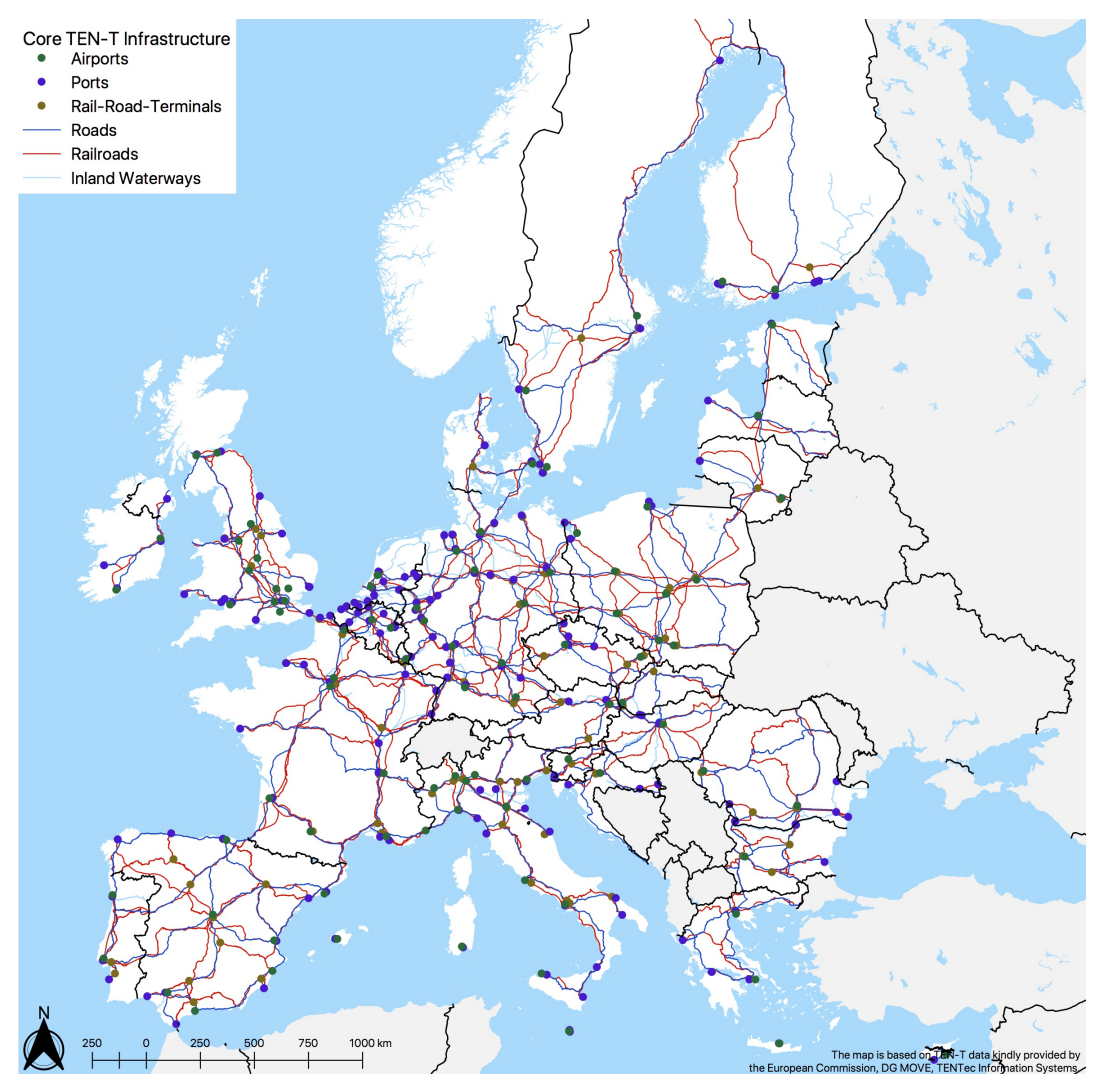

Figure 1. : TEN-T Core Infrastructure

To achieve the aforementioned goals, several EU funding instruments are available which comprise, among others, the Connecting Europe Facility (CEF), the European Structural and Investment Funds (ESI) and the European Fund for Strategic Investments (EFSI). In connection with the eastern enlargement of the EU, the 12 new Member States have already invested more than 40 billion Euros in TEN-T projects between 2007 and 2013 (European Commission, 2018b). Between 2014 and 2016, approximately 600 projects with a total volume of 21 billion Euros were co-funded by the CEF, while 34 billion Euros have been programmed for TEN-T infrastructure during the period 2014-2020 (European Commission, 2017). Given that huge investments are made in these transport corridors, it is important to look carefully at the outcome in order to evaluate whether the investments are justified.

\section{Literature Review}

While there is considerable literature on growth effects of transport infrastructure in general, research on the effectiveness of the TEN-T initiative is relatively scarce. Looking at the body of literature that deals with transport infrastructure in general, it becomes evident that transport infrastructure can have substantial effects on regional growth (Chen and Haynes, 2015; Álvarez-Ayuso et al., 2016). 
Households as well als firms can gain from market expansions caused by lower transaction and transport costs (Lakshmanan, 2011).

Moreover, not only the region where new infrastructure is built, but also neighboring regions can be affected by these investments. This observation goes back to the first law of geography, which states that "everything is related to everything else, but near things are more related than distant things" (Tobler, 1970, p. 236). Accordingly, LeSage (2008) states that in empirical studies, it is often observed that regions close to each other observe similar values. Thus, they are not independent from each other, but spatially dependent. This may be due to externalities of physical and human capital, technological interdependence (Ertur and Koch, 2007), cultural influences, infrastructure, and other reasons (LeSage, 2008).

These externalities can cause economic spillovers on region $j$ due to a change in region $i$. This change can, for instance, be an increase in physical capital caused by the construction of a new road. There are various reasons why there might be positive as well as negative spillover effects of transport infrastructure on neighboring regions. On the one hand, positive spillovers can be caused by a reduction in transport costs that increases economic activities due to access to new markets (Crescenzi et al., 2016). On the other hand, spillovers can also be negative if infrastructure improvements of neighboring regions lead to an emigration of companies and of skilled labour (Crescenzi et al., 2016).

Positive spillover effects of transport infrastructure investment are, for instance, found by Álvarez-Ayuso and Delgado Rodríguez (2012); Chen and Haynes (2015). Álvarez-Ayuso and Delgado Rodríguez (2012) incorporate the monetary capital stock of high-capacity roads in a regional production function for Spanish regions. They find a small positive impact on private production. This positive impact increases when adjacent regions are taken into account. Therefore, they conclude that there are positive spillovers for high-capacity road infrastructure. This result is confirmed by Chen and Haynes (2015), who find that transport infrastructure has a positive impact on regional growth in the US eastern metropolitan region. They also find high positive spillover effects on adjacent regions. Including highway, public rail, public transit, and public airport infrastructure, they find that highway infrastructure outweighs the effects of other transport modes.

As an extension of this finding, some authors find that positive growth effects depend on certain conditions like the region's income (Álvarez-Ayuso et al., 2016) or its government quality (Crescenzi et al., 2016). Regions with high income and high government quality benefit most from investments in transportation infrastructure and receive positive spillover effects. These results call into question the ability of transport investments to promote balanced regional growth and interregional cohesion.

Positive direct output effects can, however, also be accompanied by negative output spillovers, as pointed out by Crescenzi et al. (2016). Boarnet (1998) obtains a similar result for monetary public infrastructure capital in Californian counties. Bo and Florio (2012) confirm this result for European NUTS2 regions, underlining the positive impact of investment in the quality and quantity of infrastructure on Gross Domestic Product (GDP). The negative spatial spillovers might, however, be driven by infrastructure types other than transport. Moreover, their regional units are quite large, implying that spillover effects might be relatively small (Álvarez-Ayuso et al., 2016).

As there are reasons why spillover effects can be positive or negative, there are 
also papers that find no significant spillover effects. Holtz-Eakin and Schwartz (1995), for example, find no productivity spillovers from state highways within the U.S. Accordingly, Crescenzi and Rodríguez-Pose (2012) find neither positive direct nor indirect effects of the length of EU 15 motorways on regional growth. They argue that factors like social values, investment in R\&D and migration are more important.

Besides the aforementioned papers that deal with transport infrastructure in general, there are also some papers that focus on transport investments made within the TEN-T initiative. Gutiérrez and Urbano (1996), for example, analyze the Trans-European Road Network plans that were formulated in the 1990s to generate higher accessibility of remote regions by 2002 . They show that the area of the EU that lies within $40 \mathrm{~km}$ of the closest road corridor increases from $70 \%$ to $85 \%$ due to these plans. They also state that more distant regions can benefit most from the accessibility increases.

Combining an EU macroeconomic model and EU transport models, Köhler et al. (2008) also find a small positive economic effect of a faster completion of TEN-T infrastructure projects. They do not, however, include the scenario of not completing the TEN-T infrastructure projects at all.

Due to the fact that the often-applied national cost-benefit analyses do not account for positive spillover effects on other countries, Gutiérrez et al. (2011) argue that supra-national planning and financing of transport infrastructure is especially important for projects approaching the border perpendicularly. For this reason, they propose a method for calculating a European added value of TEN-T projects. They show that there are substantial spillover effects, even in countries whose territory is not crossed by the corridor.

Bröcker et al. (2010) measure the performance of TEN-T on a project basis, investigating whether spillover effects or the contribution to spatial cohesion justify EU subsidies for the TEN-T network. They use a spatial computable general equilibrium model to calculate changes in the welfare of households in different regions caused by new TEN-T infrastructure and the resulting transport cost reductions. Their results suggest that only 12 of 22 projects are profitable regarding their direct and indirect economic effects captured by their model, and only five projects have spillovers large enough to justify EU subsidies. Therefore, they conclude that subsidies are not justified.

Papadaskalopoulos et al. (2005) investigate the spatial impact of TEN-T corridors in the Balkan area. Thus, they pursue a similar objective to ours, although for a slightly different geographic area. They investigate 185 urban centers and construct a spatial weight matrix based on direct land-transport connections. They find that TEN-T corridors are a significant factor in the spatial reallocation of economic activities and that there are both winning and losing regions. The latter are characterized by unfavorable topography and, similar to Crescenzi et al. (2016), political instability.

In contrast to the aforementioned papers that focus on road infrastructure, Vickerman et al. (1999) analyze changes in high-speed rail accessibility due to TEN-T investments by the EU. They find that, in contrast to the policy objective of cohesion, the development of the high-speed rail network widens, rather than narrows the differences in accessibility between central and peripheral regions. Although this effect contrasts to the generally positive results for road infrastructure, this negative result seems plausible, as the high-speed rail network can only have few access points. 
In most of the above-mentioned papers, road infrastructure is proxied by the length or density of road or motorway networks or by monetary capital stocks. These infrastructure indicators, however, do not adequately indicate removed bottlenecks or improved connectivity due to new connections to transport networks (Crescenzi and Rodríguez-Pose, 2012). For this reason, we use a dummy variable that shifts from 0 to 1 when a TEN-T core corridor road segment is completed in a given NUTS3 region. Also, a variable that accounts for the effect of the TEN$\mathrm{T}$ core corridor road network density within a NUTS3 region is included in the regression setup at all times. Moreover, we control for the presence of other transport infrastructure, like the density of overall highways and of railway lines, in the sensitivity analyses (Section VII). Through the corridor dummy variable, we account for the above-mentioned bottleneck-removing and accessibility-improving effects of newly constructed road segments. These features are also proclaimed by the EU as the main goals of the TEN-T policy. To the best of our knowledge, we are the first to quantify the direct and indirect economic effects of newly gained access to the TEN-T core network. Consequently, we directly address the targets of the TEN-T policy and state whether it contributes to regional growth and might therefore contribute to cohesion.

\section{Data}

In order to estimate the different economic effects of TEN-T corridors on NUTS3 regions, we collected data from various sources. All in all, our data sample consists of 3,615 observations that were obtained for 241 NUTS3 regions of the EU Eastern Enlargement countries between 2001 and 2015. ${ }^{1}$

In our analysis, the economic variable of interest is GDP growth of a NUTS3 region. Accordingly, we take GDP level values from Eurostat and construct annual growth rates.

The data on the TEN-T corridors were kindly provided by the European Commission, DG MOVE, TENtec Information System. This dataset offers information on the infrastructure types of roads, railroads, inland waterways, seaports, airports, and rail-road terminals co-financed by the TEN-T initiative. The dataset differentiates between 3,539 road segments, 3,712 railroad segments, 883 inland waterway segments, 554 seaports, 353 airports, and 220 rail-road terminals. All of these infrastructure segments or sites can be assigned to either the core network or the comprehensive network. An overview of the core network can be seen in Figure 1.

For roads, railroads, and inland waterways, the dataset offers further information on whether a certain infrastructure segment was completed, planned, under construction/ongoing, or under study/preparation. This differentiation is displayed for roads in Figure 2.

Furthermore, it is specified whether the construction of a specific segment was a new construction, an upgrade, a rehabilitation, or whether this information was not measured. An overview of these differently categorized, already completed road segments can be seen in Figure 3.

For the panel data analysis of the economic impacts of TEN-T corridors, we focus on newly constructed segments of the road network that have already been

These countries include Bulgaria, Croatia, Cyprus, Czech Republic, Estonia, Hungary, Latvia, Lithuania, Malta, Poland, Romania, Slovenia, and Slovakia. 


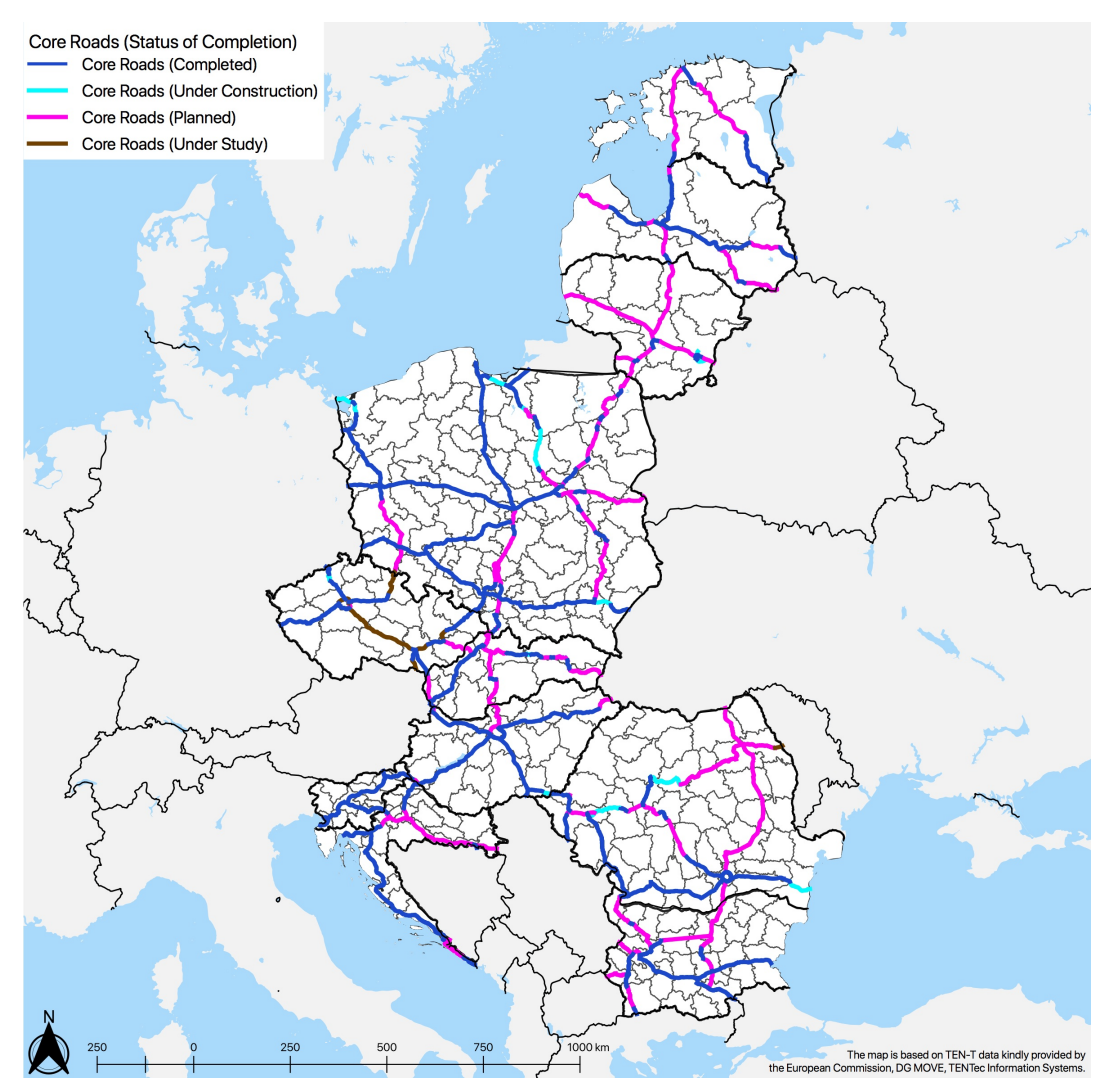

Figure 2. : TEN-T Core Roads by Status of Completion

completed. ${ }^{2}$ This is due to the availability of information on the completion of TEN-T corridor segments; while this information could be obtained from various sources for the road network, similarly detailed information was not available for the railroad network. However, as can be seen in Figure 1, railroads often run parallel to road corridors and therefore through the same NUTS3 regions as the TEN-T core roads. Additionally, the ports, airports, and rail-road terminals are often in close proximity to the core road network. To isolate the effect of the TEN-T road corridors, we also control for other infrastructure types (Section VII). Thus, the focus on the road network should not cause any serious disturbances in the estimation results.

To estimate infrastructure growth effects on a NUTS3 region, we check whether there was a newly constructed TEN-T core corridor road segment built in this NUTS3 region during the considered time period. If this was the case, the panel dummy variable for this NUTS3 region takes on the value 0 in years prior to completion, and the value 1 if the newly constructed TEN-T core corridor road segment had already been completed and could be used at the beginning of the year. ${ }^{3}$ NUTS3 regions where a new TEN-T core corridor road segment was built can be seen in Figure $4 .{ }^{4}$ For the NUTS3 regions colored in light grey, the new

2 It should be noted that this data is based on the information provided by the European Commission and dated 9th March of 2018.

3 Thus, our indicator variable bears close resemblance to the indicator variable used in Michaels (2008). One notable difference, however, is that our indicator variable can change over time.

4 If two or more road segments were built within one NUTS3 region, the dummy variable shifts from 


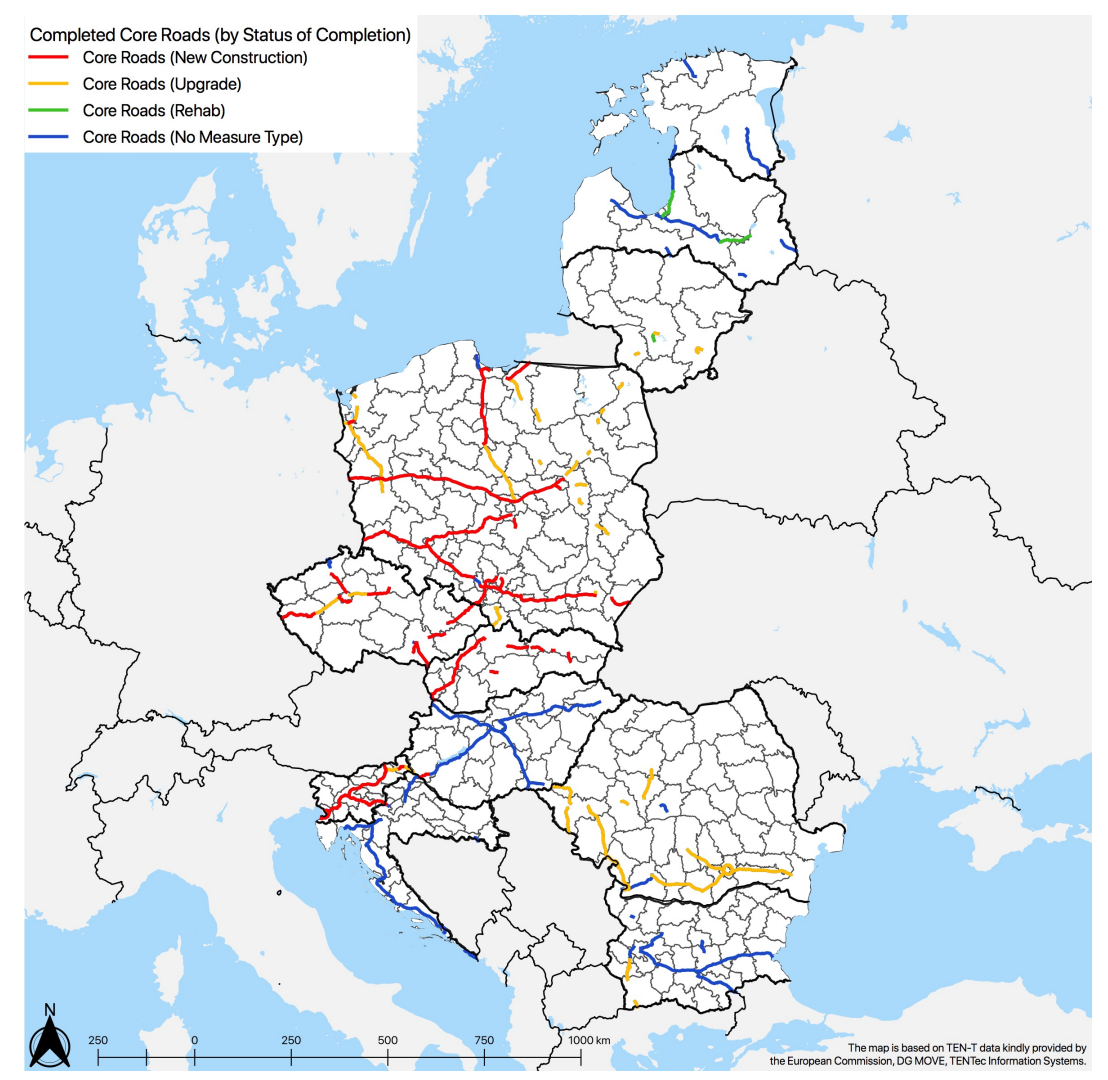

Figure 3. : Completed TEN-T Core Roads by Type of Measurement

core road segment was already completed before 2001, while for NUTS3 regions colored in darker grey, the new core road segment was completed between 2001 and 2015.

Moreover, we include a continuous variable that indicates the density of the TEN-T core corridor road network. This density variable accounts for all TEN$\mathrm{T}$ core corridor road segments that were already in use within region $i$ at the beginning of year $t$. It was calculated from the GIS data that were provided from the European Commission, DG MOVE, TENTec Information System.

\section{Panel Data Analysis}

\section{A. Theory}

As our data has a cross-sectional dimension with the 241 NUTS3 regions, and a longitudinal dimension with observations from 2001 to 2015 , we use a panel data approach. In order to account for unobservable influences, we include different types of fixed effects in the regression model. As Gormley and Matsa (2014) point out, fixed effects are the best way to control for unobserved group heterogeneity. Furthermore, a Hausman test suggests that fixed effects are preferred over random effects for our panel data set.

The four different regression models that we apply are presented in Equations 


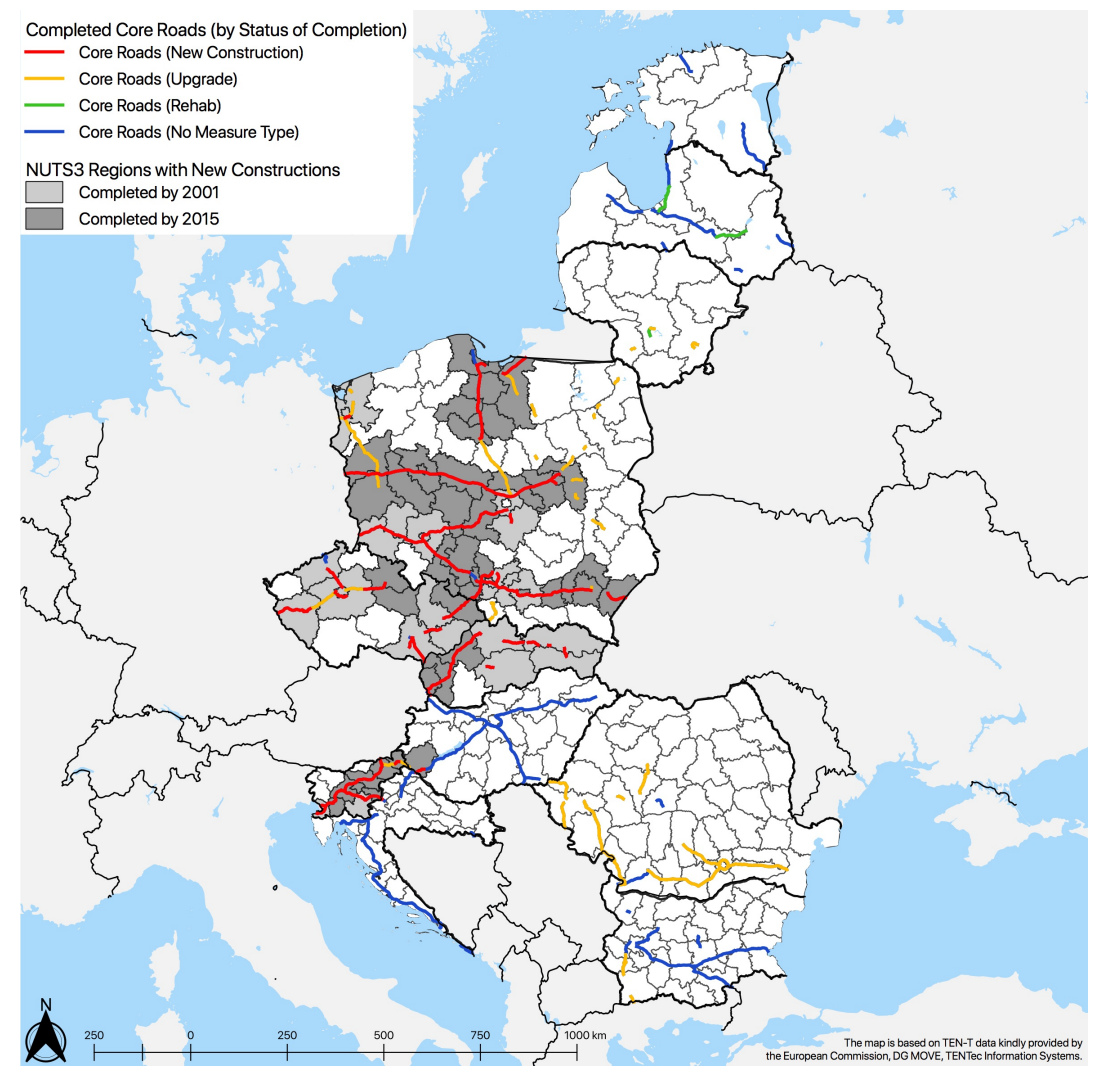

Figure 4. : NUTS3 Regions where a new TEN-T core corridor road segment is built

1 to 4 :

(1)

gdp_growth cit $_{1}=\beta_{1}$ corridor_dummy $_{c i t}+\beta_{2}$ corridor_density cit $_{-}+\lambda_{t}+\mu_{c}+\varepsilon_{c i t}$

(2)

gdp_growth cit $_{-}=\beta_{1}$ corridor_dummy $y_{c i t}+\beta_{2}$ corridor_density $y_{c i t}+\lambda_{t}+\nu_{i}+\varepsilon_{c i t}$

(3)

$g d p_{-} g r o w t h_{c i t}=\beta_{1}$ corridor_dummy $y_{c i t}+\beta_{2}$ corridor_density $y_{c i t}+\xi_{c t}+\varepsilon_{c i t}$

(4)

$g d p_{-} g r o w t h_{c i t}=\beta_{1}$ corridor_dummy $y_{c i t}+\beta_{2}$ corridor_density $y_{c i t}+\nu_{i}+\xi_{c t}+\varepsilon_{c i t}$.

In these equations, gdp_growth $h_{c i t}$ denotes the growth of the GDP of region $i$ in country $c$ and year $t$. The dummy variable corridor_dummy $y_{c i t}$ indicates whether a newly constructed road segment in region $i$ was (already) completed in year $t .^{5}$ Consequently, this dummy variable accounts for direct access to the TEN-T core corridor road network. The variable corridor_densitycit indicates the density of the completed TEN-T core corridor road network within region $i$ at the beginning of year $t$ (in $\mathrm{km} / \mathrm{km}^{2}$ ). The error term is denoted by $\epsilon_{i c t}$.

In Equation 1, we include country fixed effects $\left(\mu_{c}\right)$ and time fixed effects $\left(\lambda_{t}\right)$. 
Thus, this regression model captures the specific characteristics of a country that are fixed over time. Time fixed effects capture time trends or cyclical aspects that affect all NUTS3 regions equally within one year. In Equation 2, we substitute the country fixed effects with NUTS3 fixed effects $\left(\nu_{i}\right)$, consequently allowing NUTS3 regions within a country to systematically differ from each other with respect to their fixed effects. This approach is also used by Michaels (2008). As a third option, we include country-year fixed effects $\left(\xi_{c t}\right)$ in Equation 3. They capture the unique idiosyncrasies of one country in a specific year, thus time trends might differ from one country to another country. The regression model that is presented in Equation 4 features country-year fixed effects as well as NUTS3 fixed effects. Consequently, the regression model structure is similar to those in Dell et al. (2014) or Gormley and Matsa (2014), where similarly structured problems are analyzed.

In order to manage the large number of multi-way fixed effects, we employ the Stata command "reghdfe" from Correia (2016). One advantage of this command is the careful estimation of the degrees of freedom in a multi-way fixed effects setting that accounts for nesting within clusters, as well as possible sources of collinearity within fixed effects. Thereby, the significance levels of our estimates are calculated more accurately.

Error terms are clustered at the NUTS3 level, as we believe that the observations for a given NUTS3 region are not independent over time. This clustering procedure makes standard errors, and thus inferences, robust to serial correlation and heteroskedasticity (Wooldridge, 2016, p. 433).

\section{B. Results of the Panel Data Regression}

The results of these regression analyses are presented in Table 1. The effect of a

Table 1-: Results of the Panel Data Analysis

\begin{tabular}{|c|c|c|c|c|}
\hline & (1) & $(2)$ & $(3)$ & $(4)$ \\
\hline corridor_dummy & $\begin{array}{l}0.007^{* * *} \\
(0.002)\end{array}$ & $\begin{array}{l}0.020^{* *} \\
(0.008)\end{array}$ & $\begin{array}{c}0.001 \\
(0.003)\end{array}$ & $\begin{array}{c}0.005^{* *} \\
(0.002)\end{array}$ \\
\hline corridor_density & $\begin{array}{c}0.192 \\
(0.133)\end{array}$ & $\begin{array}{c}0.279 \\
(0.266)\end{array}$ & $\begin{array}{c}0.194 \\
(0.133)\end{array}$ & $\begin{array}{c}-0.011 \\
(0.095)\end{array}$ \\
\hline Observations & 3615 & 3615 & 3600 & 3600 \\
\hline$R^{2}$ & 0.544 & 0.559 & 0.773 & 0.787 \\
\hline Year Fixed Effects & Yes & Yes & No & No \\
\hline Country Fixed Effects & Yes & No & No & No \\
\hline NUTS3 Fixed Effects & No & Yes & No & Yes \\
\hline Country-Year Fixed Effects & No & No & Yes & Yes \\
\hline
\end{tabular}

newly created TEN-T core corridor road segment on the GDP growth of a NUTS3 region is positive in three of four specifications. When we use year and country fixed effects in the regression model (Column 1), the construction of a TEN-T core corridor road segment increases GDP growth by 0.7 percentage points. When employing year and NUTS3 fixed effects (Column 2), this effect even increases to 
roughly 2 percentage points. This increase in the growth effect magnitude might indicate that there is substantial variation between NUTS3 regions of the same country.

If we allow for cyclical effects to vary across different countries (Column 3), the usual year fixed effects can no longer be included in the regression due to perfect multicollinearity issues. In this specification, the GDP growth effect of a newly created TEN-T core corridor road segment becomes insignificant. When NUTS3 fixed effects are considered additionally (Column 4), the effect is again significant at around 0.5 percentage points. It should be noted that Specification (4) accounts for the most differentiated fixed effects, and should thus be considered to be the most realistic panel regression specification.

In contrast to the corridor dummy variable, the corridor density variable is insignificant in all specifications. This implies that the existing corridor length in relation to the region's geographical size does not have a positive growth effect. Thus, it appears that regional GDP growth is driven by direct access to the TEN$\mathrm{T}$ core corridor road network, and not by the density of the TEN-T road network within this region. In the next section, we test whether the results hold when we account for spatial spillover effects.

\section{Spatial Analysis}

\section{A. Theory of Spatial Analysis}

We are interested in the regional spillover effects of access to newly constructed TEN-T core corridor roads on growth in neighboring countries. To estimate these spillover effects, we employ the spatial Durbin model (SDM), which can account for spatial dependence of the dependent variable $y$ on the dependent variable itself, as well as for spatial dependence on other independent variables. This controls for unobservable regional factors and can thereby mitigate omitted variable bias.

To achieve these features, spatial lag terms are added to the regression. These are linear combinations of the variable values from all neighboring regions. The spatial lag term of the dependent variable $y$ for region $i$ can consequently be written as $\sum_{j=1}^{n} w_{i j} y_{j}$, where $w_{i j}$ is an element that describes the relationship between regions $i$ and $j$. In most cases, $w_{i j}$ is a dummy variable that takes on the value 1 if regions $i$ and $j$ are contiguous, and 0 otherwise. Switching to matrix notation, we can create a $n \times n$ spatial weight matrix $W_{C}$ for contiguity, which has the elements $w_{i j}$ (LeSage and Pace, 2009).

Then, an SDM that includes spatial lags of the dependent variable $y$ and spatial lags of a set of explanatory variables $X$, thereby accounting for externalities of these variables, can be written as follows (LeSage and Pace, 2009):

$$
\begin{aligned}
& y=\alpha \iota_{n}+\rho W_{C} y+X \beta+W_{C} X \gamma+\varepsilon \\
& \varepsilon \sim N\left(0, \sigma^{2} I_{n}\right),
\end{aligned}
$$

where $\alpha$ is a parameter and $\iota_{n}$ is a vector of ones. Thus, the first term on the right allows for situations where the mean of vector $y$ is different from zero. The scalar parameter $\rho$ reflects the strength of spatial dependence. Note that if $\rho=0$, there is no spatial dependence on the dependent variable $y$. In general, the matrix $X$ represents the set of independent variables, which are the indicator variable corridor_dummy and the continuous variable corridor_density for our 
estimation setup. Vectors $\beta$ and $\gamma$ are the regression coefficients in which we are interested. Furthermore, we also include NUTS3 and year fixed effects to control for unobserved factors that are constant for NUTS3 regions and for different time periods.

LeSage and Pace (2009) show that when using ordinary least squares (OLS), the estimates of the spatial parameters, of regression parameters for models with spatially lagged dependent variables, and of error terms, can be inconsistent. We therefore follow Lee (2004) and LeSage and Pace (2009) and use a maximum likelihood estimation technique, implemented via the "xsmle" command in Stata (Belotti et al., 2016).

\section{B. Creation of Spatial Weight Matrices}

The spatial weight matrix $W_{C}$ that gives the contiguity relations for the NUTS3 regions of our sample was created with GeoDa from a Eurostat map of the EU and its NUTS3 regions. Contiguity is defined following the rook criterion. The main diagonal consists of zeros to prevent regions from being neighbors to themselves. Furthermore, the spatial weight matrix $W_{C}$, and all other spatial weight matrices that are considered within our regression analysis, are row-standardized, so that the sum of each row would equal unity.

In addition to the contiguity-indicating spatial weight matrix $W_{C}$, we create three more spatial weight matrices. The spatial weight matrix $W_{G}$ accounts for the economic distance between two regions and is theoretically based on gravity type models. The elements $w_{i j}$ of this spatial weight matrix take on the values $w_{i j}=\frac{G D P_{2001, i} \times G D P_{2001, j}}{d_{i j}^{2}}$ if $i \neq j$, and 0 if $i=j .{ }^{6}$ We use GDP values from 2001, the beginning of our observation period, to exclude feedback effects from other model variables, which in turn ensures the exogeneity of the spatial weight matrix $W_{G}$ (Corrado and Fingleton, 2012). The variable $d_{i j}$ refers to the euclidean distance between two regions. Thus, the elements $w_{i j}$ of the spatial weight matrix approximate trade flows between NUTS3 regions. Subsequently, the spatial weight matrix $W_{G}$ does not only capture spillover effects on neighboring regions, but also on more distant regions and especially on regions that are important trading partners.

For the next spatial weight matrix, we depart from the stricter notion of Tobler's 1970 first law of geography. The matrix should thus no longer indicate spatial proximity, but focus on whether two regions are connected through a TEN-T core road network section, and is denoted as $W_{N}$. Therefore, we define 30 sections of the TEN-T core corridor road network in countries of the Eastern Enlargement. These 30 sections are mostly constructed as parts of the core corridor network that $(i)$ lie on the same national or international E-road network (and can thus be driven without switching to another road), and ( $i i$ ) form a fairly straight connection between two distant points. Because the weights of the matrix do not have to reflect contiguity, but can rather indicate any kind of potential interaction, connection, or otherwise defined nearness (Anselin, 1988; Anselin and Bera, 1998; Leenders, 2002), we declare two regions $i$ and $j$ to be connected with each other, if the same corridor section runs through both regions. The elements of the weight

6 The GDP of the exporting country $i$ can also be excluded from the calculation, as it is nullified when row-standardizing the spatial weight matrix (Corrado and Fingleton, 2012). 
matrix $W_{N}$ then take on the following values:

$$
w_{i j}= \begin{cases}1 & \begin{array}{l}
\text { if NUTS3 regions } i \text { and } j \text { are connected through } \\
\text { one of the } 30 \text { corridor sections }
\end{array} \\
0 & \text { otherwise }\end{cases}
$$

An example of this procedure is presented in Figure 5 in Appendix B for the A2 highway in Poland, which is one of the 30 corridor sections.

The spatial weight matrix $W_{C N}$ combines information from the spatial weight matrices $W_{C}$ and $W_{N}$. Two regions are now declared to be connected if they are contiguous and if they are also penetrated by the same corridor section. Thus, the created spatial weight matrix is similar to the one used by LeSage and Polasek (2008). This matrix can be calculated as the Hadamard product of matrices $W_{C}$ and $W_{N}$ :

$$
W_{C N}=W_{C} \circ W_{N} .
$$

Hence, the matrix $W_{C N}$ contains the intersecting set of information of the first two information sets and identifies regions that are contingent and connected by the corridor.

\section{Results of the Spatial Analysis}

The four weighting matrices outlined above can be used in the SDM, in order to estimate spatial autocorrelation and the spatial dependence of economic growth on the explanatory variables. The results of regressions with these four differently specified weighting matrices can be found in Table 2 .

The estimated regression coefficients of the SDM do not account for feedback loops, which represent situations where region $i$ affects region $j$, and region $j$ also has an impact on region $i$ (or even longer paths). In order to account for these feedback loops, we compute and analyze the average direct effects $(D E)$, average indirect effects $(I E)$, and average total effects $(T E)$, as outlined in LeSage and Pace (2009). The average direct effect gives the impact of a unit change in the explanatory variable of region $i$ on the dependent variable of region $i$, averaged over all regions. The average total effect represents the impact of a unit change in the explanatory variable of all regions on the dependent variable of region $i$, averaged over all regions. As $T E=D E+I E$, the average indirect effect is thus the impact of a unit change in the explanatory variable of all regions except region $i$ on the dependent variable in region $i$, averaged over all regions (LeSage, 2008; Belotti et al., 2016). The three outlined effects basically describe a new steady state equilibrium, caused by the original changes in infrastructure and its feedback effects (LeSage and Pace, 2009).

Because the four specifications in Table 2 differ with respect to the underlying spatial weight matrix, we can test whether results are driven by a specific spatial weight matrix. We can therefore account for four different ways in which effects can spread to the hinterland. It can be seen that there is a significant and positive average direct effect in Specifications (2), (3), and (4). Although the effect magnitude is similar in Specification (1), the coefficient is insignificant for this specification. Nevertheless, the results of Specifications (2) to (4) appear to confirm the results of the panel analysis. For the SDM, the direct effect of the 
Table 2-: Results of the Spatial Analysis

\begin{tabular}{|c|c|c|c|c|}
\hline & $\begin{array}{c}\text { Contiguity } \\
{\left[W_{C}\right]} \\
(1)\end{array}$ & $\begin{array}{l}\text { Gravity } \\
{\left[W_{G}\right]} \\
(2)\end{array}$ & $\begin{array}{c}\text { Corridor } \\
{\left[W_{N}\right]} \\
(3)\end{array}$ & $\begin{array}{c}\text { Corridor-Contiguity } \\
{\left[W_{C N}\right]} \\
(4)\end{array}$ \\
\hline \multicolumn{5}{|l|}{ Explanatory Variables } \\
\hline corridor_dummy & $\begin{array}{c}0.004 \\
(0.005)\end{array}$ & $\begin{array}{c}0.006 \\
(0.005)\end{array}$ & $\begin{array}{l}0.011^{* *} \\
(0.005)\end{array}$ & $\begin{array}{c}0.007 \\
(0.005)\end{array}$ \\
\hline corridor_density & $\begin{array}{c}0.138 \\
(0.231)\end{array}$ & $\begin{array}{c}0.217 \\
(0.186)\end{array}$ & $\begin{array}{c}0.244 \\
(0.219)\end{array}$ & $\begin{array}{c}0.253 \\
(0.258)\end{array}$ \\
\hline \multicolumn{5}{|l|}{ Spatial Lags } \\
\hline corridor_dummy & $\begin{array}{c}0.015^{*} \\
(0.009)\end{array}$ & $\begin{array}{c}0.021^{*} \\
(0.012)\end{array}$ & $\begin{array}{c}0.030 \\
(0.018)\end{array}$ & $\begin{array}{l}0.020^{* *} \\
(0.009)\end{array}$ \\
\hline corridor_density & $\begin{array}{c}0.332 \\
(0.381)\end{array}$ & $\begin{array}{c}-0.075 \\
(0.280)\end{array}$ & $\begin{array}{c}0.933 \\
(1.032)\end{array}$ & $\begin{array}{c}0.085 \\
(0.349)\end{array}$ \\
\hline \multicolumn{5}{|l|}{ Spatial Dependence } \\
\hline$\rho$ & $\begin{array}{l}0.608^{* * * *} \\
(0.020)\end{array}$ & $\begin{array}{l}0.744^{* * * *} \\
(0.025)\end{array}$ & $\begin{array}{l}0.468^{* * *} \\
(0.032)\end{array}$ & $\begin{array}{l}0.378^{* * * *} \\
(0.023)\end{array}$ \\
\hline \multicolumn{5}{|l|}{ Variance } \\
\hline$\sigma^{2}$ & $\begin{array}{l}0.003^{\text {*** }} \\
(0.000)\end{array}$ & $\begin{array}{l}0.003^{\text {*** }} \\
(0.000)\end{array}$ & $\begin{array}{l}0.003^{* * *} \\
(0.000)\end{array}$ & $\begin{array}{l}0.003^{\text {*** }} \\
(0.000)\end{array}$ \\
\hline \multicolumn{5}{|l|}{ Direct Effect } \\
\hline corridor_dummy & $\begin{array}{c}0.008 \\
(0.006)\end{array}$ & $\begin{array}{c}0.009^{*} \\
(0.005)\end{array}$ & $\begin{array}{l}0.013^{* *} \\
(0.006)\end{array}$ & $\begin{array}{c}0.010^{*} \\
(0.005)\end{array}$ \\
\hline corridor_density & $\begin{array}{c}0.192 \\
(0.279)\end{array}$ & $\begin{array}{c}0.214 \\
(0.212)\end{array}$ & $\begin{array}{c}0.268 \\
(0.225)\end{array}$ & $\begin{array}{c}0.255 \\
(0.268)\end{array}$ \\
\hline \multicolumn{5}{|l|}{ Indirect Effect } \\
\hline corridor_dummy & $\begin{array}{l}0.044^{* *} \\
(0.021)\end{array}$ & $\begin{array}{l}0.097^{* *} \\
(0.044)\end{array}$ & $\begin{array}{c}0.050^{*} \\
(0.026)\end{array}$ & $\begin{array}{l}0.025^{\text {*** }} \\
(0.009)\end{array}$ \\
\hline corridor_density & $\begin{array}{c}0.838 \\
(1.018)\end{array}$ & $\begin{array}{c}0.190 \\
(1.253)\end{array}$ & $\begin{array}{c}1.237 \\
(1.450)\end{array}$ & $\begin{array}{c}0.142 \\
(0.378)\end{array}$ \\
\hline \multicolumn{5}{|l|}{ Total Effect } \\
\hline corridor_dummy & $\begin{array}{l}0.051^{* *} \\
(0.024)\end{array}$ & $\begin{array}{l}0.106^{* *} \\
(0.046)\end{array}$ & $\begin{array}{l}0.063^{* *} \\
(0.028)\end{array}$ & $\begin{array}{l}0.035^{\text {*** }} \\
(0.010)\end{array}$ \\
\hline corridor_density & $\begin{array}{c}1.030 \\
(1.227) \\
\end{array}$ & $\begin{array}{c}0.404 \\
(1.402) \\
\end{array}$ & $\begin{array}{c}1.505 \\
(1.518) \\
\end{array}$ & $\begin{array}{c}0.397 \\
(0.532)\end{array}$ \\
\hline Observations & 3615 & 3615 & 3615 & 3615 \\
\hline$R^{2}$ & 0.470 & 0.422 & 0.431 & 0.465 \\
\hline Year Fixed Effects & Yes & Yes & Yes & Yes \\
\hline NUTS3 Fixed Effects & Yes & Yes & Yes & Yes \\
\hline
\end{tabular}

$* \mathrm{p}<0.1,{ }^{* *} \mathrm{p}<0.05, * * * \mathrm{p}<0.01$. Standard errors in parentheses.

Source: Own calculation.

Note: The first part of the regression table contains the actual regression output. The second part of the regression output contains the direct, indirect, and total effects that were calculated as in Belotti et al. (2016) and LeSage (2008). These effects account for feedback effects and are thus more relevant for the interpretation of the results.

creation of a TEN-T core corridor road segment lies between 0.009 and 0.013 , thus implying that newly gained access to the TEN-T core corridor road network increases GDP growth of this region by 0.9 to 1.3 percentage points.

Both the average indirect effect and the average total effect are significant in all four specifications. Thus, we can conclude that access to the TEN-T core corridor road network not only entails benefits to regions that gain this access, but also to the other regions in the sample. The indirect effect of Specification (1) with the spatial weight matrix $W_{C}$ accounts for spillover effects on neighboring regions and also for feedback effects that stem from higher-order neighbors, which reflects the global nature of the spillover effects of the SDM (LeSage, 2014). As these neighboring regions (or higher-order neighbors) do not necessarily need to have access to the TEN-T network, the positive results imply that spillover 
effects also accrue to regions that are not directly affected by the TEN-T policy. Consequently, the TEN-T policies targeting road projects can also bring benefits to rather remote regions.

This can also be confirmed by the second specification, where the spatial weight matrix $W_{G}$ accounts for a spatially uneven distribution of economic activity. Spillover effects might not accrue mainly to geographically closer regions as in Specification (1), but also to more distant regions that are economically strong and thus important trading partners. For these regions, the spillover effects appear to be even larger than for the closer regions.

For specifications (3) and (4), it should be kept in mind that the spatial weight matrices $W_{N}$ and $W_{C N}$ are constructed in such a way that regions that do not have access to the TEN-T core corridor road network are technically unconnected to any of the other regions in the sample. Thus, they are islands and the global spillover effects of the SDM do not reach these island regions. ${ }^{7}$ Consequently, the spillover effects would only accrue to regions that are part of the TEN-T core corridor road network.

In Specification (3), the indirect effects with the spatial weight matrix $W_{N}$ are assumed not to spread from NUTS3 region to NUTS3 region, but from corridor section to corridor section. As each of the 30 corridor sections consists of more than one NUTS3 region, the dissemination of spillover effects would be more far-reaching than for Specifications (1) or (4). The results show that spillover effects for Specification (3) are larger than in Specifications (1) and (4). They are, however, smaller than in gravity-type Specification (2), which also accounts for more far-reaching spillover effects on NUTS3 regions without direct access to the TEN-T core corridor road network. This difference can again be attributed to the fact that the spatial weight matrix $W_{N}$, which is used in Specification (3), restricts spillover effects to only accrue to NUTS3 regions with direct access to the TEN-T core corridor road network. Thus, we can again conclude that a substantial part of the overall spillover effect would accrue to regions without direct access to the TEN-T core road network.

In Specification (4), the indirect effect with the spatial weight matrix $W_{C N}$ accounts for effects on neighboring regions that also lie on the TEN-T core corridor road network, and also for feedback effects from higher-order neighbors that lie on the core corridor roads. It is now interesting to note that the indirect effect of Specification (4) is much smaller than for the less restrictive Specification (1). Keeping in mind that the main difference between the two spatial weight matrices $W_{C}$ and $W_{C N}$ is the restriction that indirect effects for $W_{C N}$ only accrue to NUTS3 regions with corridor access, whereas indirect effects for $W_{C}$ also accrue to unconnected regions, the difference in the indirect effect magnitudes between (1) and (4) implies that a significant share of the spillovers would indeed accrue to regions that do not have direct access to the TEN-T core corridor road network. Regarding the TEN-T policy objective of cohesion, this result is quite important,

$7 \quad$ This can be seen by looking at the spatial multiplier matrix, which is decomposed in Elhorst (2014) as follows: $(\mathbf{I}-\delta \mathbf{W})^{-1}=\mathbf{I}+\delta \mathbf{W}+\delta^{2} \mathbf{W}^{2}+\delta^{3} \mathbf{W}^{3} \ldots$ Here, the higher powers of $\mathbf{W}$ are responsible for the fact that feedback effects from second-order neighbors $\left(\mathbf{W}^{2}\right)$, third-order neighbors $\left(\mathbf{W}^{3}\right)$, etc. impact on the average indirect effect. This is due to the fact that regions that are unconnected in $\mathbf{W}$ might be connected in $\mathbf{W}^{2}$ or higher powers of $\mathbf{W}$. Consequently, the indirect effects are global spillovers that stem from all regions in the sample (although regions that are only connected in higher powers of $\mathbf{W}$ impact on the spillover effect to a lesser degree). Regions that are islands, however, are not connected to any other region in $\mathbf{W}$, and thus they are also not connected to any other regions in higher powers of $\mathbf{W}$. This implies that the spillover effects from Specifications (3) and (4) would only accrue to regions that are penetrated by a TEN-T core corridor road segment. 
as this infrastructure also exerts positive effects on more distant regions. Moreover, this result may also remove pressure from policy makers to find the ideal corridor route, as unaffected regions also benefit.

These results underline that significant spillover effects stem from access to the TEN-T core corridor road network. The results also imply that these spillover effects not only accrue to NUTS3 regions with direct access to the TEN-T core corridor road network, but also to NUTS3 regions that are not directly connected to the TEN-T core corridor road network.

Similar to the panel data analysis in Section V, the density of the TEN-T core corridor road network is insignificant in all specifications. Thus, neither direct nor indirect GDP growth effects would stem from the TEN-T core corridor road network density. This result is in line with Crescenzi and Rodríguez-Pose (2012), who argue that infrastructure endowment alone is a poor indication of economic growth.

To check the robustness of these results, we conduct several sensitivity analyses in the next section.

\section{Sensitivity Analysis}

\section{A. Additional Control Variables}

Besides the access to the TEN-T core corridor road network and the different fixed effects, the GDP growth could of course be influenced by a variety of other factors. If possible, we attempt to generate information on such factors at the NUTS3 level. One additional control variable accounts for the population at the NUTS3 level and six different variables control for the employment in different economic sectors at the NUTS3 level. ${ }^{8}$ Furthermore, a dummy variable indicates whether the NUTS3 region was already part of the EU in year $t$. If, on the other hand, the information is not available at the NUTS3 level, we use information at the NUTS2 level. At the NUTS2 level, we include the density of all motorways (in $\left.\mathrm{km} / \mathrm{km}^{2}\right)^{9}$ and the density of total railway lines (in $\mathrm{km} / \mathrm{km}^{2}$ ). Thus, we now account for the impact that overall motorways and total railway lines might have on regional GDP growth. Moreover, we include six variables on the gross fixed capital formation and six variables on the compensation of employees in the aforementioned six different economic sectors of the NUTS2 regions. ${ }^{10}$

The results of this sensitivity analysis can be found in Table 4 in Appendix C. They indicate that our basic results are robust to the inclusion of additional control variables. In the first two specifications, we have a slightly smaller growth effect. The growth effect of the third specification is now significant and lies around 0.4 percentage points. In the last specification with country-year and NUTS3 fixed effects, the growth effect is even stronger than in the basic regression model.

Similar to the density of the TEN-T core corridor road network, the density of the overall motorway network within a region does not have a significant effect

8 The six economic sectors that are considered are: A, B-E, F, G-J, K-N, O-U of the NACE Revision 2 classification. An overview of all variables can also be found in Table 3 in Appendix A.

$9 \quad$ It should be noted that the density of all motorways within a region is closely related to the density of TEN-T core corridor roads. In order to avoid problems caused by multicollinearity, we only include the density of all motorways in this part of the sensitivity analysis.

10 The variables described in this section are from Eurostat. Only the EU dummy variable was created by ourselves, based on the years of accession to the EU. 
on regional GDP growth in all of the four considered regression specifications. The density of total railway lines, on the other hand, has a small negative effect on regional GDP growth in the first specification, but is insignificant in the three specifications that account for more differentiated fixed effects.

Due to some missing values in the additional control variables, we cannot conduct this sensitivity analysis for our SDM.

\section{B. Lagging infrastructure variables}

In our initial regression setup, we assume that there is an immediate growth effect of the TEN-T core corridor road completion. This, however, might not always be true as growth effects could also occur after the completion, thus signifying a phase-in effect. We therefore add a one year lag of the TEN-T core corridor dummy variable and of the TEN-T core corridor density variable to the initial model. Furthermore, this one-year lag mitigates endogeneity concerns.

The results of a regression setup that includes a contemporaneous and a lagging variable can be found in Tables 5 and 6 in Appendix D. The first two regression specifications indicate that there is no longer a significant growth effect. Nevertheless, the regression specifications in Column (3) and (4), which account for more differentiated fixed effects, show that there is still a significant growth effect, which is slightly larger than in the standard regression setup and which emerges rather close to the completion of the new TEN-T core corridor road segment. Both the contemporaneous as well as the lagging density variables are again insignificant in all specifications, thus supporting the notion that regional GDP growth is rather induced by access to the TEN-T network than by increases in the density of the TEN-T network within a region.

The spatial analysis with contemporaneous and lagging infrastructure variables indicates, surprisingly, that there is no significant direct effect. It should be noted that this insignificance stands in stark contrast to nearly all other analyses, where there are positive direct growth effect of newly gained access to the TEN$\mathrm{T}$ core corridor road network. ${ }^{11}$ There are, however, positive indirect and total growth effects in three of the four specifications. The magnitudes of these effects are higher than in the basic regression setup. It is interesting to see that the growth effects for Specifications (1) and (4), which account for spillover effects on contiguous regions as well as on regions that are contiguous and lie on the same corridor section, emerge closer to the completion of the new TEN-T core corridor road segment. On the other hand, Specification (3) shows that spillover effects on regions that lie on the same corridor section, however, emerge to a later date. Considering that regions on the same corridor section can be much farther away from each other than neighboring regions, it appears plausible that spillover effects on such regions might take longer to emerge than spillover effects on adjacent regions.

\section{Effect on GDP per capita}

In addition to the GDP growth effect of TEN-T corridor access, we also analyze the effect on Gross Domestic Product per capita (GDPPC) growth in order to

11 Please also note that adding temporal dimensions to spatial models could indeed lead to different results, although both models are correctly specified. For a more detailed discussion of this, however, we refer to LeSage and Pace (2009, pp. 189 ff.). 
test whether individuals benefit in a similar fashion to the regional economy as a whole. ${ }^{12}$ The results of these analyses can be found in Tables 7 and 8 in Appendix E.

According to the panel analysis, a new TEN-T core corridor road segment impacts on GDP and GDPPC in an almost identical manner. When spatial effects are included as part of the SDM, it appears that the direct and indirect effects of a newly constructed TEN-T core corridor road segment are almost identical for GDP growth as well as for GDPPC growth.

\section{Discussion}

Both the panel data and the spatial analysis yield significant and positive NUTS3 regional GDP growth effects of a newly constructed TEN-T core corridor road segment. Depending on the specification, this effect lies between 0.5 and 2.0 percentage points for the panel data analysis and between 0.9 and 1.3 for the spatial analysis. Thus, the TEN-T corridors can increase economic growth at the NUTS3 level.

By reviewing the literature on growth effects of transport infrastructure investments, Romp and de Haan (2007) find that the growth effect depends crucially on the extent to which bottlenecks are removed. We cannot explicitly determine whether our positive growth effects are due to the removal of bottlenecks or caused by generally improved accessibility in Eastern European regions. However, as we focus on the EU TEN-T policy which aims especially at removing bottlenecks, we incorporate the effects of bottleneck-removing infrastructure in our analysis. Thus, our results are in line with the findings of Romp and de Haan (2007).

Our results seem to contrast with Crescenzi and Rodríguez-Pose (2012), who conclude that there is no significant evidence that road infrastructure can contribute to GDP growth of the own or of neighboring regions. ${ }^{13}$ There are, however, some important differences to our analysis. While we estimate growth effects at the NUTS3 level, Crescenzi and Rodríguez-Pose (2012) resort to effects on the larger NUTS2 or NUTS1 regions. Our deeper level of disaggregation comes at the cost of fewer available control variables, which we try to circumvent through the use of various fixed effect specifications. Also, Crescenzi and Rodríguez-Pose (2012) use kilometers of motorway standardized by regional population as their infrastructure measurement. Our focus, on the other hand, is not on the quantity of infrastructure, but rather on access to the TEN-T core corridor network. Thus, the positive direct growth effects that we estimate can be attributed to an increase in the connectivity of a region. When looking at our corridor density variable, however, we also find no positive direct or indirect effects, just like Crescenzi and Rodríguez-Pose (2012).

Elburz et al. (2017) employ a meta-analysis on 912 observations from 42 studies and find that public infrastructure in the United States is more likely to have negative regional growth effects, whereas public infrastructure in the EU is more likely to have positive regional growth effects. Our own study is thus in line with these findings.

A study by Bo and Florio (2012), for example, finds positive direct effects as

12 Information on GDPPC are taken from Eurostat.

13 It should be noted that Crescenzi and Rodríguez-Pose (2012) find a significant and positive spatial impact of infrastructure in one region on GDP growth in a neighboring region for their fixed effects within regressions. 
well as negative indirect effects for investments in infrastructure on GDP for European NUTS2 level regions. Our results, on the other hand, indicate that the positive spillover effects of newly constructed roads of the TEN-T core corridor project, such as a better connectivity between regions, exceed negative spillover effects caused by increased competition. Since we use data at a lower level of aggregation, we are better able to isolate and estimate spillover effects. Moreover, they use a broadly defined infrastructure measure which, besides transport infrastructure, also includes telecommunications and broadband infrastructure. As negative spillovers of the latter two infrastructure types seem plausible due to higher competitive effects, their results of overall negative spatial spillovers therefore seem to be dominated by telecommunications and broadband infrastructure.

Vickerman et al. (1999) show that improvements in the earlier rail corridor network widened the differences in accessibility between central and peripheral regions. Therefore, they conclude that the earlier rail corridor network was unable to achieve stronger convergence in accessibility and economic performance of European countries. We show that increases in accessibility by road transport corridors can cause economic growth in the Eastern European NUTS3 regions, which were, generally speaking, lagging behind Western European NUTS3 regions in economic terms. Hence, the TEN-T road projects might contribute to economic growth and convergence after all.

In conclusion, we can state that the extent and sign of direct and indirect effects seem to depend on the type of infrastructure analyzed. It seems plausible that road infrastructure, which can also be accessed easily from the periphery, has positive spatial impacts, whereas rail corridors and especially the high-speed rail network rather benefits central regions and therefore could widen differences in accessibility between central and peripheral regions. While growth effects from investments in broadband infrastructure seem to be very local, road transport TEN-T-corridors seem to provide benefits for a larger catchment area.

We also show that these positive spillover effects not only accrue to regions that have access to the TEN-T core corridor road network, but also to regions that are not directly connected to the network. Thus, the TEN-T policy helps not only to improve economic performance of regions that gain access to the TEN-T network, but also regions that are not directly affected by the creation of new corridors. At the same time, the exact route of the core corridor roads becomes less important. This could reduce conflicts between different regional authorities, who would all try to have corridor roads in their region.

As our infrastructure dummy variable only takes on the value 1 if, within a given region, a TEN-T core corridor road segment was already completed on January 1st of the considered year, we consequently estimate the ex post impact of TEN-T core corridor access on regional GDP growth. The sensitivity analysis with lagged variables indicates that indirect spillover effects appear rather close to the completion in regions that are closer to the newly built TEN-T core corridor road segment, but that they are are lagged by one year for more distant regions. This suggests that the growth effects spread outward from the point of origin over time.

The positive direct effects of access to the TEN-T core corridor network underline that the TEN-T project helps to remove bottlenecks, increases a NUTS3 region's connectivity and thus contributes positively to economic performance. The elimination of bottlenecks and improved access to important transport networks are consequently a viable way to support distant regions in their endeavors 
to participate in national and international economic activities. This can also have further positive impacts on the hinterland. Moreover, our results indicate that TEN-T policy indeed succeeds in fostering economic cohesion, since the construction of new corridor road segments, for which our positive growth effects are calculated, is concentrated mainly in Eastern European countries that need to catch up with the Western European countries.

\section{Conclusion}

We use a panel data approach to estimate the regional NUTS3 GDP growth effects that stem from newly gained access to the TEN-T core corridor road network in EU Eastern Enlargement countries. This growth effect is positive and ranges, depending on the specification, between 0.5 and 2.0 percentage points. The density of the TEN-T core corridor road network within a NUTS3 region, on the other hand, has no significant effect on growth rates.

The spatial analysis confirms that the direct GDP growth effect of newly gained access to the TEN-T core corridor road network is between 0.9 and 1.3 percentage points. Moreover, we calculate indirect effects of the creation of TEN-T core road segments using four different spatial weight matrices. We find positive spillover effects for newly gained access to the TEN-T core corridor road network. These spillover effects do not only accrue to regions that lie on the core corridor roads, but also to regions that are not directly connected to the TEN-T core corridor road network. Given that our results show that not only the regions where EU-funded corridor infrastructure is built profit from corridor roads, the EU TEN-T policy might indeed contribute to economic cohesion between central and peripheral regions, as well as between Eastern and Western European countries.

The results are robust to various fixed effects specifications, additional control variables, and a specification with lagged and contemporaneous infrastructure variables. Moreover, the results can be upheld if GDPPC serves as the dependent variable. Our paper could be extended in various ways. As indicated by Figure 2, more corridor segments will be completed by 2030. Future research should expand our analysis to these corridor segments. As the data on the TEN-T also indicate upgrades of existing infrastructure, future research should also analyze these upgrades to determine whether they lead to significant growth effects for NUTS3 regions.

Although our results cannot be regarded as an exhaustive analysis of the complete EU TEN-T transport policy program, they nonetheless provide evidence that, apart from improved conditions for transit traffic, infrastructure investments also have positive effects on regional GDP growth along the corridor. For this reason, TEN-T policy contributes to economic cohesion and a stronger internal market. Thus, the EU should continue working on the highways of European countries in order to advance their cohesion policy.

\section{Acknowledgements}

The authors would like to thank three anonymous referees and Gernot Sieg for their helpful comments. 


\section{Appendices}

\section{A. Overview of Variables}

Table 3-: Overview of Variables

\begin{tabular}{|c|c|c|}
\hline Variable & Source & Description \\
\hline coe_a & Eurostat & $\begin{array}{l}\text { Compensation of employees in the sector "agriculture, forestry and } \\
\text { fishing" [in million Euros]. }\end{array}$ \\
\hline$c o e \_b \_e$ & Eurostat & $\begin{array}{l}\text { Compensation of employees in the sector "industry (except construc- } \\
\text { tion)" [in million Euros]. }\end{array}$ \\
\hline $\mathrm{coe}_{-} f$ & Eurostat & $\begin{array}{l}\text { Compensation of employees in the sector "construction" [in million } \\
\text { Euros]. }\end{array}$ \\
\hline $\mathrm{Coe}_{-} g_{-} j$ & Eurostat & $\begin{array}{l}\text { Compensation of employees in the sector "wholesale and retail trade; } \\
\text { transport; accommodation and food service activities; information } \\
\text { and communication" [in million Euros]. }\end{array}$ \\
\hline$c o e_{-} k_{-} n$ & Eurostat & $\begin{array}{l}\text { Compensation of employees in the sector "financial and insurance } \\
\text { activities; real estate activities; professional, scientific and technical } \\
\text { activities; administrative and support service activities" [in million } \\
\text { Euros]. }\end{array}$ \\
\hline coe_o_u & Eurostat & $\begin{array}{l}\text { Compensation of employees in the sector "public administration and } \\
\text { defence; compulsory social security; education; human health and } \\
\text { social work activities; arts, entertainment and recreation, repair of } \\
\text { household goods and other services" [in million Euros]. }\end{array}$ \\
\hline corridor_dummy & Authors/EC & $\begin{array}{l}\text { Dummy variable that indicates whether a newly constructed road } \\
\text { segment in region } i \text { was (already) completed in year } t \text {. }\end{array}$ \\
\hline corridor_density & Authors/EC* & $\begin{array}{l}\text { Continuous variable that indicates the density of the completed TEN- } \\
\mathrm{T} \text { core corridor road network within region } i \text { at the beginning of year } \\
t\left[\text { in } \mathrm{km} / \mathrm{km}^{2}\right] \text {. }\end{array}$ \\
\hline employment_a & Eurostat & Employment in the sector "agriculture, forestry and fishing" [in 1000]. \\
\hline employment_b_e & Eurostat & Employment in the sector "industry (except construction)" [in 1000]. \\
\hline employment_f & Eurostat & Employment in the sector "construction" [in 1000]. \\
\hline employment_g $g_{-} j$ & Eurostat & $\begin{array}{l}\text { Employment in the sector "wholesale and retail trade; transport; ac- } \\
\text { commodation and food service activities; information and communi- } \\
\text { cation" [in 1000]. }\end{array}$ \\
\hline employment_k_n & Eurostat & $\begin{array}{l}\text { Employment in the sector "financial and insurance activities; real } \\
\text { estate activities; professional, scientific and technical activities; ad- } \\
\text { ministrative and support service activities" [in 1000]. }\end{array}$ \\
\hline employment_o_u & Eurostat & $\begin{array}{l}\text { Employment in the sector "public administration and defence; com- } \\
\text { pulsory social security; education; human health and social work ac- } \\
\text { tivities; arts, entertainment and recreation, repair of household goods } \\
\text { and other services" [in 1000]. }\end{array}$ \\
\hline gdp_growth & Eurostat & Total GDP growth over all sectors within a NUTS3 region. \\
\hline$g f c f_{-} a$ & Eurostat & $\begin{array}{l}\text { Gross fixed capital formation in the sector "agriculture, forestry and } \\
\text { fishing" [in million Euros]. }\end{array}$ \\
\hline$g f c f_{-} b_{-} e$ & Eurostat & $\begin{array}{l}\text { Gross fixed capital formation in the sector "industry (except con- } \\
\text { struction)" [in million Euros]. }\end{array}$ \\
\hline$g f c f_{-} f$ & Eurostat & $\begin{array}{l}\text { Gross fixed capital formation in the sector "construction" [in million } \\
\text { Euros]. }\end{array}$ \\
\hline$g f c f_{-} g_{-} j$ & Eurostat & $\begin{array}{l}\text { Gross fixed capital formation in the sector "wholesale and retail trade; } \\
\text { transport; accommodation and food service activities; information } \\
\text { and communication" [in million Euros]. }\end{array}$ \\
\hline$g f c f \_k \_n$ & Eurostat & $\begin{array}{l}\text { Gross fixed capital formation in the sector "financial and insurance } \\
\text { activities; real estate activities; professional, scientific and technical } \\
\text { activities; administrative and support service activities" [in million } \\
\text { Euros]. }\end{array}$ \\
\hline$g f c f \_o \_u$ & Eurostat & $\begin{array}{l}\text { Gross fixed capital formation in the sector "public administration } \\
\text { and defence; compulsory social security; education; human health } \\
\text { and social work activities; arts, entertainment and recreation, repair } \\
\text { of household goods and other services" [in million Euros]. }\end{array}$ \\
\hline railway_lines_total & Eurostat & Indicates the density of total railway lines $\left(\right.$ in $\left.\mathrm{km} / \mathrm{km}^{2}\right)$. \\
\hline roads_motorways & Eurostat & Indicates the density of all motorways (in $\mathrm{km} / \mathrm{km}^{2}$ ). \\
\hline
\end{tabular}

Note: ${ }^{*}$ These variables were created by the authors, based on information that were kindly provided by the European Commission, DG MOVE, TENTec Information System. 


\section{B. Creation of the Spatial Weight Matrix $W_{N}$}

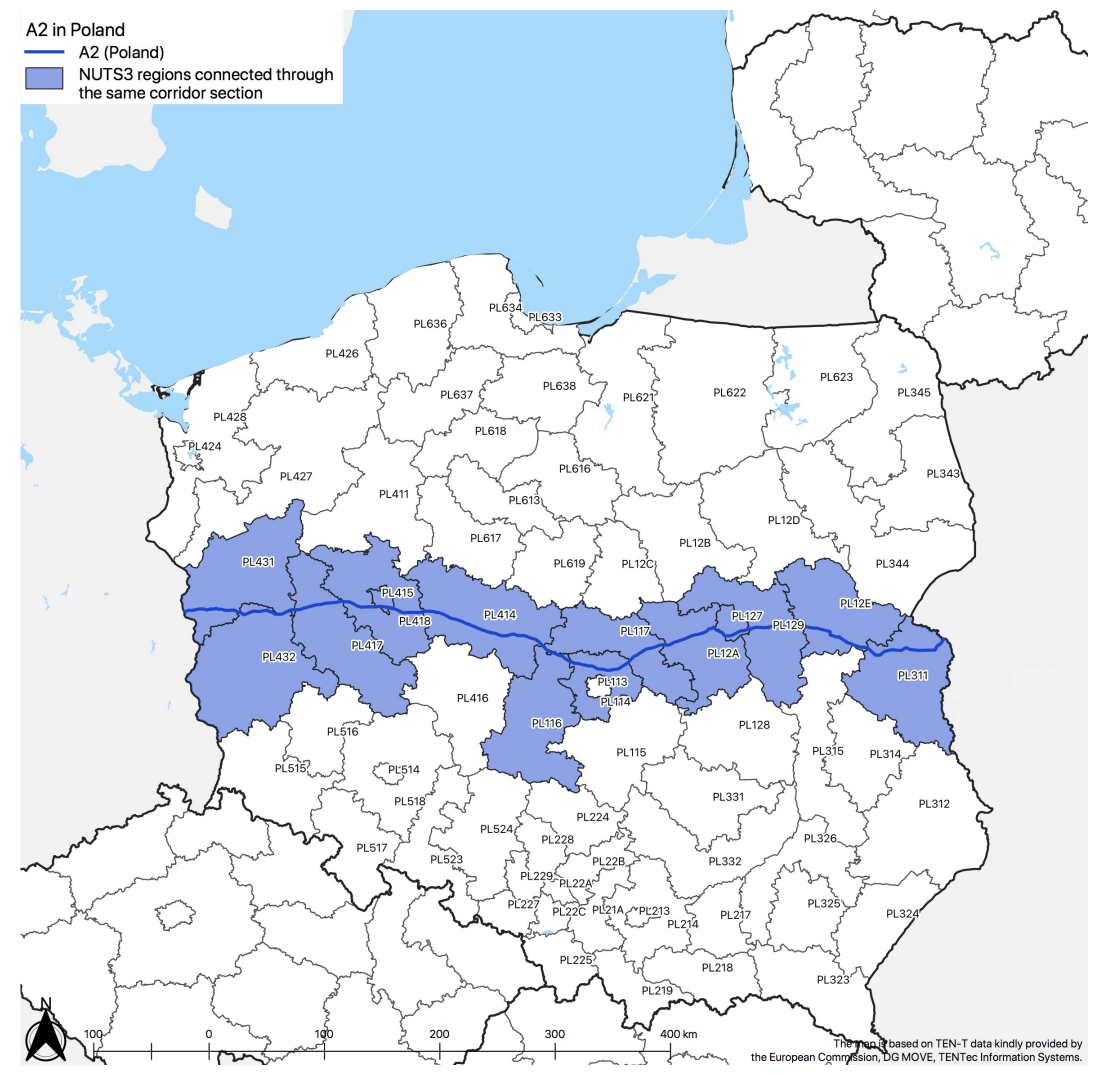

Figure 5. : Creation of the Spatial Weight Matrix $W_{N}$. Example: A2 in Poland

NUTS3 regions along the same corridor section are declared to be connected to each other. Figure 5 shows the pathway of the Polish highway A2, which is one of our 30 considered corridor sections. Consequently, all NUTS3 regions through which the corridor section passes, that is, all blue NUTS3 regions in Figure 5, are declared to be connected to each other. 


\section{Sensitivity Analysis - Additional Control Variables}

Table 4-: Panel Data Analysis with Additional Control Variables

\begin{tabular}{|c|c|c|c|c|}
\hline & (1) & $(2)$ & (3) & (4) \\
\hline \multirow[t]{2}{*}{ corridor_dummy } & $0.00579^{* *}$ & $0.01443^{* *}$ & $0.00418^{* * *}$ & $0.00975^{* * *}$ \\
\hline & $(0.00250)$ & $(0.00618)$ & $(0.00107)$ & $(0.00219)$ \\
\hline \multirow[t]{2}{*}{ roads_motorways } & -0.00002 & -0.00002 & 0.00002 & -0.00001 \\
\hline & $(0.00003)$ & $(0.00009)$ & $(0.00002)$ & $(0.00004)$ \\
\hline \multirow[t]{2}{*}{ railway_lines_total } & $-0.00001^{* * *}$ & 0.00000 & -0.00000 & -0.00000 \\
\hline & $(0.00000)$ & $(0.00002)$ & $(0.00000)$ & $(0.00001)$ \\
\hline \multirow[t]{2}{*}{ eu_dummy } & -0.01612 & -0.00554 & 0.00000 & 0.00000 \\
\hline & $(0.03014)$ & $(0.02615)$ & $(0.00000)$ & $(0.00000)$ \\
\hline \multirow[t]{2}{*}{ employment_a } & $0.00181^{* * *}$ & $0.00445^{* *}$ & $0.00061^{* *}$ & -0.00090 \\
\hline & $(0.00049)$ & $(0.00167)$ & $(0.00025)$ & $(0.00101)$ \\
\hline \multirow[t]{2}{*}{ employment_b_e } & $0.00035^{* * *}$ & $0.00116^{* * *}$ & $0.00017^{* *}$ & 0.00018 \\
\hline & $(0.00006)$ & $(0.00034)$ & $(0.00007)$ & $(0.00013)$ \\
\hline \multirow[t]{2}{*}{ employment_f } & 0.00043 & 0.00105 & 0.00032 & $0.00070^{*}$ \\
\hline & $(0.00045)$ & $(0.00086)$ & $(0.00043)$ & $(0.00034)$ \\
\hline \multirow[t]{2}{*}{ employment_g_j } & 0.00007 & -0.00056 & $0.00016^{*}$ & -0.00027 \\
\hline & $(0.00029)$ & $(0.00088)$ & $(0.00008)$ & $(0.00021)$ \\
\hline \multirow[t]{2}{*}{ employment_k_n } & 0.00038 & 0.00110 & -0.00010 & -0.00015 \\
\hline & $(0.00049)$ & $(0.00119)$ & $(0.00011)$ & $(0.00042)$ \\
\hline \multirow[t]{2}{*}{ employment_o_u } & $-0.00039^{* *}$ & -0.00020 & -0.00009 & 0.00067 \\
\hline & $(0.00014)$ & $(0.00034)$ & $(0.00010)$ & $(0.00037)$ \\
\hline \multirow[t]{2}{*}{ gfcf_a } & 0.00006 & $0.00013^{* * *}$ & $0.00002^{*}$ & $0.00006^{* *}$ \\
\hline & $(0.00003)$ & $(0.00003)$ & $(0.00001)$ & $(0.00002)$ \\
\hline \multirow[t]{2}{*}{ gfcf_b_e } & -0.00001 & -0.00001 & 0.00000 & 0.00001 \\
\hline & $(0.00001)$ & $(0.00001)$ & $(0.00000)$ & $(0.00001)$ \\
\hline \multirow[t]{2}{*}{ gfcf_f } & -0.00000 & -0.00000 & $0.00000^{*}$ & 0.00000 \\
\hline & $(0.00000)$ & $(0.00000)$ & $(0.00000)$ & $(0.00000)$ \\
\hline \multirow[t]{2}{*}{ gfcf_g_j } & $0.00004^{* *}$ & $0.00003^{*}$ & $0.00001^{* * *}$ & $0.00001^{* * *}$ \\
\hline & $(0.00001)$ & $(0.00002)$ & $(0.00000)$ & $(0.00000)$ \\
\hline \multirow[t]{2}{*}{ gfcf_k_n } & -0.00001 & -0.00001 & $-0.00000^{* *}$ & -0.00000 \\
\hline & $(0.00001)$ & $(0.00001)$ & $(0.00000)$ & $(0.00000)$ \\
\hline \multirow[t]{2}{*}{ gfcf_O_u } & $0.00003^{* *}$ & 0.00004 & 0.00000 & 0.00001 \\
\hline & $(0.00001)$ & $(0.00002)$ & $(0.00001)$ & $(0.00002)$ \\
\hline \multirow[t]{2}{*}{ coe_a } & 0.00000 & 0.00004 & -0.00001 & $0.00004^{* *}$ \\
\hline & $(0.00006)$ & $(0.00009)$ & $(0.00001)$ & $(0.00001)$ \\
\hline \multirow[t]{2}{*}{ coe_b_e } & 0.00000 & 0.00001 & -0.00001 & $-0.00001^{*}$ \\
\hline & $(0.00001)$ & $(0.00002)$ & $(0.00000)$ & $(0.00000)$ \\
\hline \multirow[t]{2}{*}{ coe_f } & $0.00005^{*}$ & 0.00004 & $0.00002^{*}$ & 0.00004 \\
\hline & $(0.00003)$ & $(0.00004)$ & $(0.00001)$ & $(0.00002)$ \\
\hline \multirow[t]{2}{*}{$\operatorname{coe}_{-} \mathrm{g}_{-} \mathrm{j}$} & $-0.00004^{* *}$ & $-0.00003^{*}$ & $-0.00001^{* * *}$ & -0.00000 \\
\hline & $(0.00001)$ & $(0.00002)$ & $(0.00000)$ & $(0.00001)$ \\
\hline \multirow[t]{2}{*}{ coe_k_n } & 0.00002 & 0.00001 & -0.00000 & -0.00002 \\
\hline & $(0.00001)$ & $(0.00003)$ & $(0.00001)$ & $(0.00002)$ \\
\hline coe_O_u & -0.00000 & -0.00001 & $0.00001^{* *}$ & 0.00001 \\
\hline & $(0.00001)$ & $(0.00003)$ & $(0.00000)$ & $(0.00001)$ \\
\hline Observations & 2721 & 2721 & 2721 & 2721 \\
\hline$R^{2}$ & 0.655 & 0.673 & 0.805 & 0.816 \\
\hline Year Fixed Effects & Yes & Yes & No & No \\
\hline Country Fixed Effects & Yes & No & No & No \\
\hline NUTS3 Fixed Effects & No & Yes & No & Yes \\
\hline Country-Year Fixed Effects & No & No & Yes & Yes \\
\hline
\end{tabular}

$* \mathrm{p}<0.1,{ }^{*} * \mathrm{p}<0.05, * * * \mathrm{p}<0.01$. Standard errors in parentheses.

Source: Own calculation. 


\section{Sensitivity Analysis - Lags and Leads}

Table 5-: Panel Data Analysis with Different Time Dimensions

\begin{tabular}{lcccc}
\hline & $(1)$ & $(2)$ & $(3)$ & $(4)$ \\
\hline corridor_dummy & 0.00908 & 0.01585 & $0.01492^{*}$ & $0.01523^{*}$ \\
& $(0.00949)$ & $(0.01259)$ & $(0.00718)$ & $(0.00700)$ \\
corridor_dummy_lag1 & -0.00107 & 0.00834 & -0.01406 & -0.01471 \\
& $(0.01071)$ & $(0.01444)$ & $(0.00930)$ & $(0.01103)$ \\
corridor_density & 0.49527 & 0.44987 & 0.06216 & -0.16227 \\
& $(0.42614)$ & $(0.62162)$ & $(0.05321)$ & $(0.18989)$ \\
corridor_density_lag1 & -0.30511 & -0.37087 & 0.13829 & 0.04513 \\
& $(0.43264)$ & $(0.48238)$ & $(0.16337)$ & $(0.16957)$ \\
\hline Observations & 3374 & 3374 & 3360 & 3360 \\
$R^{2}$ & 0.551 & 0.567 & 0.784 & 0.800 \\
Year Fixed Effects & Yes & Yes & No & No \\
Country Fixed Effects & Yes & No & No & No \\
NUTS3 Fixed Effects & No & Yes & No & Yes \\
Country-Year Fixed Effects & No & No & Yes & Yes \\
\hline
\end{tabular}

${ }^{*} \mathrm{p}<0.1,{ }^{* *} \mathrm{p}<0.05,{ }^{* * *} \mathrm{p}<0.01$. Standard errors in parentheses.

Source: Own calculation. 
Table 6-: Spatial Analysis with Different Time Dimensions

\begin{tabular}{|c|c|c|c|c|}
\hline & $\begin{array}{c}\text { Contiguity } \\
{\left[W_{C}\right]} \\
(1)\end{array}$ & $\begin{array}{c}\text { Gravity } \\
{\left[W_{G}\right]} \\
(2)\end{array}$ & $\begin{array}{c}\text { Corridor } \\
{\left[W_{N}\right]} \\
(3)\end{array}$ & $\begin{array}{c}\text { Corridor-Contiguity } \\
{\left[W_{C N}\right]} \\
(4)\end{array}$ \\
\hline \multicolumn{5}{|l|}{ Explanatory Variables } \\
\hline corridor_dummy & $\begin{array}{c}0.00402 \\
(0.00834)\end{array}$ & $\begin{array}{c}0.00437 \\
(0.00882)\end{array}$ & $\begin{array}{c}0.01427 \\
(0.00882)\end{array}$ & $\begin{array}{c}0.00913 \\
(0.00945)\end{array}$ \\
\hline corridor_dummy_lag1 & $\begin{array}{c}-0.00041 \\
(0.01085)\end{array}$ & $\begin{array}{c}0.00119 \\
(0.01095)\end{array}$ & $\begin{array}{c}-0.00404 \\
(0.01106)\end{array}$ & $\begin{array}{c}-0.00253 \\
(0.01090)\end{array}$ \\
\hline corridor_density & $\begin{array}{c}0.36728 \\
(0.36473)\end{array}$ & $\begin{array}{c}0.48111 \\
(0.32060)\end{array}$ & $\begin{array}{c}0.18419 \\
(0.39010)\end{array}$ & $\begin{array}{c}0.47755 \\
(0.44060)\end{array}$ \\
\hline corridor_density_lag1 & $\begin{array}{c}-0.47291 \\
(0.29529)\end{array}$ & $\begin{array}{c}-0.51293^{*} \\
(0.28968)\end{array}$ & $\begin{array}{c}-0.11992 \\
(0.30936)\end{array}$ & $\begin{array}{c}-0.46307 \\
(0.31697)\end{array}$ \\
\hline \multicolumn{5}{|l|}{ Spatial Lags } \\
\hline corridor_dummy & $\begin{array}{c}0.03316^{*} \\
(0.01958)\end{array}$ & $\begin{array}{c}-0.00254 \\
(0.02451)\end{array}$ & $\begin{array}{c}-0.01576 \\
(0.03709)\end{array}$ & $\begin{array}{c}0.02561 \\
(0.01568)\end{array}$ \\
\hline corridor_dummy_lag1 & $\begin{array}{c}-0.01679 \\
(0.01960)\end{array}$ & $\begin{array}{c}0.02902 \\
(0.02501)\end{array}$ & $\begin{array}{c}0.06364^{*} \\
(0.03341)\end{array}$ & $\begin{array}{c}-0.00181 \\
(0.01493)\end{array}$ \\
\hline corridor_density & $\begin{array}{c}-1.58252 \\
(1.09205)\end{array}$ & $\begin{array}{c}0.18193 \\
(0.56924)\end{array}$ & $\begin{array}{c}2.27212 \\
(2.17888)\end{array}$ & $\begin{array}{r}-1.50652 \\
(1.03130)\end{array}$ \\
\hline corridor_density_lag1 & $\begin{array}{c}2.28976^{* *} \\
(1.08785)\end{array}$ & $\begin{array}{c}-0.13307 \\
(0.58143)\end{array}$ & $\begin{array}{c}-1.53454 \\
(1.88903)\end{array}$ & $\begin{array}{c}1.85788^{*} \\
(0.98480)\end{array}$ \\
\hline \multicolumn{5}{|l|}{ Spatial Dependence } \\
\hline$\rho$ & $\begin{array}{l}0.62143^{* * *} \\
(0.01995)\end{array}$ & $\begin{array}{l}0.76470^{* * *} \\
(0.02249)\end{array}$ & $\begin{array}{l}0.47570^{* * *} \\
(0.03185)\end{array}$ & $\begin{array}{l}0.39281^{* * *} \\
(0.02341)\end{array}$ \\
\hline \multicolumn{5}{|l|}{ Variance } \\
\hline$\sigma^{2}$ & $\begin{array}{l}0.00250^{* * *} \\
(0.00022)\end{array}$ & $\begin{array}{l}0.00276^{* * *} \\
(0.00021)\end{array}$ & $\begin{array}{l}0.00340^{* * *} \\
(0.00021)\end{array}$ & $\begin{array}{l}0.00323^{* * *} \\
(0.00022)\end{array}$ \\
\hline \multicolumn{5}{|l|}{ Direct Effect } \\
\hline corridor_dummy & $\begin{array}{c}0.01087 \\
(0.00966)\end{array}$ & $\begin{array}{c}0.00453 \\
(0.00945)\end{array}$ & $\begin{array}{c}0.01420 \\
(0.00901)\end{array}$ & $\begin{array}{c}0.01289 \\
(0.01003)\end{array}$ \\
\hline corridor_dummy_lag1 & $\begin{array}{c}-0.00407 \\
(0.01222)\end{array}$ & $\begin{array}{c}0.00504 \\
(0.01169)\end{array}$ & $\begin{array}{c}-0.00219 \\
(0.01127)\end{array}$ & $\begin{array}{c}-0.00342 \\
(0.01149)\end{array}$ \\
\hline corridor_density & $\begin{array}{c}0.14922 \\
(0.47784)\end{array}$ & $\begin{array}{c}0.58814 \\
(0.37185)\end{array}$ & $\begin{array}{c}0.30338 \\
(0.39050)\end{array}$ & $\begin{array}{c}0.35194 \\
(0.47409)\end{array}$ \\
\hline corridor_density_lag1 & $\begin{array}{c}-0.11245 \\
(0.38851)\end{array}$ & $\begin{array}{c}-0.60356^{*} \\
(0.33298)\end{array}$ & $\begin{array}{c}-0.19315 \\
(0.30391)\end{array}$ & $\begin{array}{c}-0.27544 \\
(0.34534)\end{array}$ \\
\hline \multicolumn{5}{|l|}{ Indirect Effect } \\
\hline corridor_dummy & $\begin{array}{c}0.08229^{*} \\
(0.04818)\end{array}$ & $\begin{array}{c}-0.00466 \\
(0.09991)\end{array}$ & $\begin{array}{c}-0.01343 \\
(0.05146)\end{array}$ & $\begin{array}{c}0.03047^{*} \\
(0.01735)\end{array}$ \\
\hline corridor_dummy_lag1 & $\begin{array}{r}-0.03867 \\
(0.04786)\end{array}$ & $\begin{array}{c}0.12850 \\
(0.10226)\end{array}$ & $\begin{array}{c}0.08317^{*} \\
(0.04622)\end{array}$ & $\begin{array}{c}-0.00262 \\
(0.01650)\end{array}$ \\
\hline corridor_density & $\begin{array}{c}-3.03478 \\
(2.81832)\end{array}$ & $\begin{array}{c}2.49697 \\
(2.77453)\end{array}$ & $\begin{array}{c}3.30247 \\
(3.05747)\end{array}$ & $\begin{array}{c}-1.36357 \\
(1.15458)\end{array}$ \\
\hline corridor_density_lag1 & $\begin{array}{c}4.61706^{*} \\
(2.73865)\end{array}$ & $\begin{array}{c}-2.35312 \\
(2.77050)\end{array}$ & $\begin{array}{c}-2.24952 \\
(2.63680)\end{array}$ & $\begin{array}{c}1.74825 \\
(1.10979)\end{array}$ \\
\hline \multicolumn{5}{|l|}{ Total Effect } \\
\hline corridor_dummy & $\begin{array}{c}0.09316^{*} \\
(0.05339)\end{array}$ & $\begin{array}{c}-0.00013 \\
(0.10310)\end{array}$ & $\begin{array}{c}0.00077 \\
(0.05273)\end{array}$ & $\begin{array}{c}0.04337^{*} \\
(0.02224)\end{array}$ \\
\hline corridor_dummy_lag1 & $\begin{array}{c}-0.04274 \\
(0.05448)\end{array}$ & $\begin{array}{c}0.13354 \\
(0.10634)\end{array}$ & $\begin{array}{c}0.08098^{*} \\
(0.04908)\end{array}$ & $\begin{array}{c}-0.00604 \\
(0.02274)\end{array}$ \\
\hline corridor_density & $\begin{array}{c}-2.88557 \\
(3.16775)\end{array}$ & $\begin{array}{c}3.08511 \\
(3.03395)\end{array}$ & $\begin{array}{c}3.60584 \\
(3.13610)\end{array}$ & $\begin{array}{c}-1.01163 \\
(1.41709)\end{array}$ \\
\hline corridor_density_lag1 & $\begin{array}{c}4.50460 \\
(3.01741) \\
\end{array}$ & $\begin{array}{c}-2.95667 \\
(3.00112) \\
\end{array}$ & $\begin{array}{c}-2.44267 \\
(2.71364) \\
\end{array}$ & $\begin{array}{c}1.47281 \\
(1.30762) \\
\end{array}$ \\
\hline Observations & 3374 & 3374 & 3374 & 3374 \\
\hline$R^{2}$ & 0.469 & 0.395 & 0.404 & 0.472 \\
\hline Year Fixed Effects & Yes & Yes & Yes & Yes \\
\hline NUTS3 Fixed Effects & Yes & Yes & Yes & Yes \\
\hline
\end{tabular}

$* \mathrm{p}<0.1,{ }^{* *} \mathrm{p}<0.05,{ }^{* * *} \mathrm{p}<0.01$. Standard errors in parentheses.

Source: Own calculation. 


\section{E. Sensitivity Analysis - Effect on GDP per capita}

Table 7-: Panel Data Analysis for GDPPC

\begin{tabular}{lcccc}
\hline & $(1)$ & $(2)$ & $(3)$ & $(4)$ \\
\hline corridor_dummy & $0.00812^{* * *}$ & $0.02208^{* *}$ & 0.00137 & $0.00490^{* * *}$ \\
& $(0.00215)$ & $(0.00879)$ & $(0.00207)$ & $(0.00141)$ \\
corridor_density & 0.11664 & 0.20142 & 0.11980 & -0.08404 \\
& $(0.07022)$ & $(0.27082)$ & $(0.06848)$ & $(0.11759)$ \\
\hline Observations & 3615 & 3615 & 3600 & 3600 \\
$R^{2}$ & 0.554 & 0.564 & 0.775 & 0.783 \\
Year Fixed Effects & Yes & Yes & No & No \\
Country Fixed Effects & Yes & No & No & No \\
NUTS3 Fixed Effects & No & Yes & No & Yes \\
Country-Year Fixed Effects & No & No & Yes & Yes \\
\hline
\end{tabular}

${ }^{*} \mathrm{p}<0.1,{ }^{* *} \mathrm{p}<0.05,{ }^{* * *} \mathrm{p}<0.01$. Standard errors in parentheses.

Source: Own calculation. 
Table 8-: Spatial Analysis for GDPPC

\begin{tabular}{|c|c|c|c|c|}
\hline & $\begin{array}{c}\text { Contiguity } \\
{\left[W_{C}\right]} \\
(1)\end{array}$ & $\begin{array}{c}\text { Gravity } \\
{\left[W_{G}\right]} \\
(2)\end{array}$ & $\begin{array}{c}\text { Corridor } \\
{\left[W_{N}\right]} \\
(3)\end{array}$ & $\begin{array}{c}\text { Corridor-Contiguity } \\
{\left[W_{C N}\right]} \\
(4)\end{array}$ \\
\hline \multicolumn{5}{|l|}{ Explanatory Variables } \\
\hline corridor_dummy & $\begin{array}{c}0.00475 \\
(0.00499)\end{array}$ & $\begin{array}{c}0.00598 \\
(0.00496)\end{array}$ & $\begin{array}{l}0.01268^{* *} \\
(0.00549)\end{array}$ & $\begin{array}{c}0.00873^{*} \\
(0.00528)\end{array}$ \\
\hline corridor_density & $\begin{array}{c}0.07880 \\
(0.25417)\end{array}$ & $\begin{array}{c}0.14564 \\
(0.20575)\end{array}$ & $\begin{array}{c}0.16601 \\
(0.23534)\end{array}$ & $\begin{array}{c}0.18481 \\
(0.28019)\end{array}$ \\
\hline \multicolumn{5}{|l|}{ Spatial Lags } \\
\hline corridor_dummy & $\begin{array}{c}0.01606^{*} \\
(0.00880)\end{array}$ & $\begin{array}{l}0.02804^{* *} \\
(0.01249)\end{array}$ & $\begin{array}{c}0.03327^{*} \\
(0.01946)\end{array}$ & $\begin{array}{l}0.02162^{* *} \\
(0.00872)\end{array}$ \\
\hline corridor_density & $\begin{array}{c}0.41954 \\
(0.38111)\end{array}$ & $\begin{array}{c}-0.15944 \\
(0.29117)\end{array}$ & $\begin{array}{c}0.97355 \\
(1.08875)\end{array}$ & $\begin{array}{c}0.08351 \\
(0.34139)\end{array}$ \\
\hline \multicolumn{5}{|l|}{ Spatial Dependence } \\
\hline$\rho$ & $\begin{array}{l}0.60775^{* * *} \\
(0.01880)\end{array}$ & $\begin{array}{l}0.73135^{\text {*** }} \\
(0.02587)\end{array}$ & $\begin{array}{l}0.45792^{* * *} \\
(0.03134)\end{array}$ & $\begin{array}{l}0.37356^{* * *} \\
(0.02289)\end{array}$ \\
\hline \multicolumn{5}{|l|}{ Variance } \\
\hline$\sigma^{2}$ & $\begin{array}{l}0.00267^{* * *} \\
(0.00021)\end{array}$ & $\begin{array}{c}0.00298^{* * *} \\
(0.00022)\end{array}$ & $\begin{array}{c}0.00357^{* * *} \\
(0.00021)\end{array}$ & $\begin{array}{l}0.00341^{* * *} \\
(0.00022)\end{array}$ \\
\hline \multicolumn{5}{|l|}{ Direct Effect } \\
\hline $\begin{array}{l}\text { corridor_dummy } \\
\text { corridor_density }\end{array}$ & $\begin{array}{c}0.00858 \\
(0.00572) \\
0.14043 \\
(0.30390)\end{array}$ & $\begin{array}{c}0.01040^{*} \\
(0.00542) \\
0.12280 \\
(0.23309)\end{array}$ & $\begin{array}{c}0.01444^{* *} \\
(0.00573) \\
0.18798 \\
(0.24161)\end{array}$ & $\begin{array}{c}0.01182^{* *} \\
(0.00535) \\
0.18167 \\
(0.29072)\end{array}$ \\
\hline \multicolumn{5}{|l|}{ Indirect Effect } \\
\hline corridor_dummy & $\begin{array}{c}0.04613^{* *} \\
(0.02107)\end{array}$ & $\begin{array}{l}0.12033^{* * *} \\
(0.04417)\end{array}$ & $\begin{array}{c}0.05399^{* *} \\
(0.02711)\end{array}$ & $\begin{array}{l}0.02677^{* * *} \\
(0.00866)\end{array}$ \\
\hline corridor_density & $\begin{array}{c}0.95510 \\
(1.03100)\end{array}$ & $\begin{array}{c}-0.32933 \\
(1.26863)\end{array}$ & $\begin{array}{c}1.20941 \\
(1.49703)\end{array}$ & $\begin{array}{c}0.11255 \\
(0.36830)\end{array}$ \\
\hline \multicolumn{5}{|l|}{ Total Effect } \\
\hline corridor_dummy & $\begin{array}{l}0.05471^{* *} \\
(0.02437)\end{array}$ & $\begin{array}{l}0.13073^{* * *} \\
(0.04630)\end{array}$ & $\begin{array}{l}0.06843^{* *} \\
(0.02883)\end{array}$ & $\begin{array}{l}0.03859^{* * *} \\
(0.01038)\end{array}$ \\
\hline corridor_density & $\begin{array}{c}1.09554 \\
(1.25793)\end{array}$ & $\begin{array}{c}-0.20652 \\
(1.43359)\end{array}$ & $\begin{array}{c}1.39739 \\
(1.56764)\end{array}$ & $\begin{array}{c}0.29422 \\
(0.54011)\end{array}$ \\
\hline Observations & 3615 & 3615 & 3615 & 3615 \\
\hline$R^{2}$ & 0.452 & 0.394 & 0.412 & 0.451 \\
\hline Year Fixed Effects & Yes & Yes & Yes & Yes \\
\hline NUTS3 Fixed Effects & Yes & Yes & Yes & Yes \\
\hline
\end{tabular}

${ }^{*} \mathrm{p}<0.1,{ }^{* *} \mathrm{p}<0.05,{ }^{* * *} \mathrm{p}<0.01$. Standard errors in parentheses.

Source: Own calculation. 


\section{REFERENCES}

Álvarez-Ayuso, I. C., Condeço-Melhorado, A. M., Gutiérrez, J., and Zofío, J. L. (2016). Integrating network analysis with the production function approach to study the spillover effects of transport infrastructure. Regional Studies, 50(6):996-1015.

Álvarez-Ayuso, I. C. and Delgado Rodríguez, M. J. (2012). High-capacity road networks and spatial spillovers in spanish regions. Journal of Transport Economics and Policy (JTEP), 46(2):281-292.

Anselin, L. (1988). Spatial Econometrics: Methods and Models. Kluwer Academic Publisher.

Anselin, L. and Bera, A. K. (1998). Spatial Dependence in Linear Regression Models with an Introduction to Spatial Econometrics. Statistics Textbooks and Monographs, 155:237-290.

Belotti, F., Hughes, G., and Mortari, A. P. (2016). Spatial Panel Data Models Using Stata. CEIS Research Paper 373, Tor Vergata University, CEIS.

Bo, C. F. D. and Florio, M. (2012). Infrastructure and Growth in a Spatial Framework: Evidence from the EU Regions. European Planning Studies, 20(8):13931414.

Boarnet, M. G. (1998). Spillovers and the locational effects of public infrastructure. Journal of Regional Science, 38(3):381-400.

Bröcker, J., Korzhenevych, A., and Schürmann, C. (2010). Assessing Spatial Equity and Efficiency Impacts of Transport Infrastructure Projects. Transportation Research Part B, 44:795-811.

Chen, Z. and Haynes, K. E. (2015). Regional Impact of Public Transportation Infrastructure: A Spatial Panel Assessment of the U.S. Northeast Megaregion. Economic Development Quarterly, 29(3):275-291.

Corrado, L. and Fingleton, B. (2012). Where Is The Economics In Spatial Econometrics? Journal of Regional Science, 52(2):210-239.

Correia, S. (2016). Linear models with high-dimensional fixed effects: An efficient and feasible estimator. Technical report. Working Paper.

Crescenzi, R., Cataldo, M. D., and Rodriguez-Pose, A. (2016). Government quality and the economic returns of transport infrastructure investment in european regions. Journal of Regional Science, 56(4):555-582.

Crescenzi, R. and Rodríguez-Pose, A. (2012). Infrastructure and Regional Growth in the European Union. Papers in Regional Science, 91(3):487-513.

Dell, M., Jones, B. F., and Olken, B. A. (2014). What Do We Learn From The Weather? The New Climate-economy Literature. Journal of Economic Literature, 52(3):740-98.

Elburz, Z., Nijkamp, P., and Pels, E. (2017). Public Infrastructure and Regional Growth: Lessons from Meta-Analysis. Journal of Transport Geography, 58:1-8. 
Elhorst, J. (2014). Spatial Econometrics: From Cross-Sectional Data to Spatial Panels. SpringerBriefs in Regional Science. Springer.

Ertur, C. and Koch, W. (2007). Growth, Technological Interdependence and Spatial Externalities: Theory and Evidence. Journal of Applied Econometrics, 22(6):1033-1062.

European Commission (2017). Delivering ten-t - facts and figures september 2017. Technical report, Directorate General for Mobility and Transport.

European Commission (2018a). About ten-t.

European Commission (2018b). Linking east and west.

Gormley, T. A. and Matsa, D. A. (2014). Common Errors: How to (and Not to) Control for Unobserved Heterogeneity. The Review of Financial Studies, $27(2): 617-661$.

Gutiérrez, J., Condeço-Melhorado, A. M., López, E., and Monzón, A. (2011). Evaluating the european added value of ten-t projects: a methodological proposal based on spatial spillovers, accessibility and gis. Journal of Transport Geography, 19:840-850.

Gutiérrez, J. and Urbano, P. (1996). Accessibility in the European Union: The Impact of the Trans-European Road Network. Journal of Transport Geography, $4(1): 15-25$.

Holtz-Eakin, D. and Schwartz, A. (1995). Spatial Productivity Spillovers from Public Infrastructure: Evidence from State Highways. International Tax and Public Finance, 2(3):459-468.

Köhler, J., Jin, Y., and Barker, T. (2008). Integrated modelling of eu transport policy. Journal of Transport Economics and Policy, 42(1):1-21.

Lakshmanan, T. (2011). The Broader Economic Consequences of Transport Infrastructure Investments. Journal of Transport Geography, 19.

Lee, L.-F. (2004). Asymptotic Distributions of Quasi-Maximum Likelihood Estimators for Spatial Autoregressive Models. Econometrica, 72(6):1899-1925.

Leenders, R. T. A. (2002). Modeling Social Influence Through Network Autocorrelation: Constructing the Weight Matrix. Social Networks, 24(1):21-47.

LeSage, J. P. (2008). An Introduction to Spatial Econometrics. Revue d'Économie Industrielle, 0(3):19-44.

LeSage, J. P. (2014). What Regional Scientists Need to Know about Spatial Econometrics. The Review of Regional Studies, 44(1):13-32.

LeSage, J. P. and Pace, R. K. (2009). Introduction to Spatial Econometrics. Chapman and Hall/CRC.

LeSage, J. P. and Polasek, W. (2008). Incorporating Transportation Network Structure in Spatial Econometric Models of Commodity Flows. Spatial Economic Analysis, 3(2):225-245. 
Michaels, G. (2008). The Effect of Trade on the Demand for Skill: Evidence from the Interstate Highway System. The Review of Economics and Statistics, 90(4):683-701.

Papadaskalopoulos, A., Karaganis, A., and Christofakis, M. (2005). The Spatial Impact of EU Pan-European Transport Axes: City Clusters Formation in the Balkan Area and Developmental Perspectives. Transport Policy, 12:488-499.

Proost, S., Dunkerley, F., Borger, B. D., Gühneman, A., Koskenoja, P., Mackie, P., and der Loo, S. V. (2011). When are Subsidies to Trans-European Network Projects Justified? Transportation Research Part A, 45:161-170.

Romp, W. and de Haan, J. (2007). Public capital and economic growth: A critical survey. Perspektiven der Wirtschaftspolitik, 8:6-52.

Tobler, W. R. (1970). A Computer Movie Simulating Urban Growth in the Detroit Region. Economic Geography, 46:234-240.

Vickerman, R., Spiekermann, K., and Wegener, M. (1999). Accessibility and Economic Development in Europe. Regional Studies, 33(1):1-15.

Wooldridge, J. (2016). Introductory Econometrics: A Modern Approach. Cengage Learning, 6 edition. 
Westfälische Wilhelms-Universität Münster, Institute of Transport Economics, Working Paper Series

22. "Time-Declining risk-adjusted social discount rates for transport infrastructure planning"

by Kathrin Goldmann, April 2017

23. "To pay or not to pay for parking at shopping malls - A rationale from the perspective of two-sided markets"

by Inga Molenda and Gernot Sieg, November 2017

24. "A duopoly of transportation network companies and traditional radio-taxi dispatch service agencies"

by Thorsten Heilker and Gernot Sieg, November 2017

25. “Airport Efficiency in Pakistan - A Data Envelopment Analysis with Weight Restrictions"

by David Ennen and Irem Batool, November 2017

26. "Economic implications of phantom traffic jams: Evidence from traffic experiments"

by Kathrin Goldmann and Gernot Sieg, December 2018

27. "Evaluating the Transport-Mode-Specific Trade Effects of Different Transport Infrastructure Types"

by Jan Wessel, February 2019

28. "The impact of delays on the welfare effects of on-track competition: The case of transfer passengers with operator-tied tickets"

by Christina Brand and Gernot Sieg, December 2019

29. “Ride-Hailing Services in Germany: Potential Impacts on Public Transport, Motorized Traffic, and Social Welfare"

by David Ennen and Thorsten Heilker, January 2020

30. "Quantifying the phantom jam externality: The case of an Autobahn section in Germany"

by Kathrin Goldmann and Gernot Sieg, March 2020

31. "TEN-T Corridors - Stairway to Heaven or Highway to Hell?" by Kathrin Goldmann and Jan Wessel, June 2020 